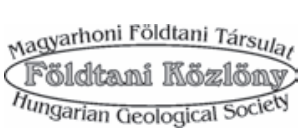

150/4, 511-528., Budapest, 2020

DOI: 10.23928/foldt.kozl.2020.150.4.511

\title{
A Balaton üledékének ásványai
}

\author{
PÓSFAI Mihály \\ Pannon Egyetem, Bio-nanotechnológiai és Mûszaki Kémiai Kutatóintézet, Nanolab \\ mihaly.posfai@gmail.com \\ ORCID: 0000-0001-9355-3533
}

\section{Minerals in the sediments of Lake Balaton}

\begin{abstract}
As the largest water body in landlocked Hungary, Lake Balaton is often affectionately referred to as the "Sea of Hungary". Given the economic, touristic and cultural significance of the lake, the preservation of its good ecological state under increasing anthropogenic pressure has always been a priority. This has been the trigger for intense scientific research over the last 130 years. Concerns about silting and eutrophication-related water quality deterioration have directed attention to the Holocene lake sediments. As a result of intense research efforts, by the end of the second half of the $20^{\text {th }}$ century the processes governing sediment accumulation were fairly well understood. This can also be said with respect to the mineralogical composition and the role of the sediment in nutrient cycles. Nevertheless, current research using modern geochemical and mineralogical techniques can reveal important new details about the major mineral components of the sediment. This review focuses on some recently-discovered features of carbonate precipitation, including the roles of clay minerals in the nucleation of calcite. Furthermore, it discusses certain groups of minerals that form under biological control. There are several lines of ongoing research that aim at obtaining a better understanding of atomic-scale details of mineral-forming processes in the lake. These efforts will also try to decipher the respective roles of mud minerals in phosphorus mobilization (a process that resulted in an unexpected algal bloom event in 2019).
\end{abstract}

Keywords: Lake Balaton, Holocene, sediment, Mg-bearing calcite, protodolomite, biomineral, phosphorus

Összefoglalás

A Balaton holocén üledékének tudományos kutatása közel 130 éve kezdődött. Az üledék felhalmozódásának törvényszerúségeit, az iszap összetételét, a tavi tápanyagforgalomban betöltött szerepét a 20 . század második felében viszonylag alaposan megismertük. Ennek ellenére a mai, modern geokémiai és ásványtani módszerekkel végzett vizsgálatok mindig újabb érdekes részletekkel gazdagítják ismereteinket. A jelen összefoglalásban elsősorban a tavi karbonátképződés jellegzetességeit, az agyagásványok kalcitképződésben játszott szerepét, valamint a biológiai folyamatok révén képződő ásványok egyes csoportjait tárgyalom. Jelenleg is több irányú, intenzív kutatás folyik egyrészt a Balatonban lejátszódó ásványképző folyamatok, másrészt az iszap ásványai és a tavi tápanyag (elsősorban a foszfor) mobilitása közötti összefüggések megértése érdekében.

Tárgyszavak: Balaton, holocén, üledék, Mg-tartalmú kalcit, protodolomit, bioásvány, foszfor

\section{Bevezetés}

Ismeretterjesztő és idegenforgalmi kiadványokban a Balatont gyakran a „magyar tenger”-ként emlegetik. Bár közhelyesnek túnhet ez a kifejezés, mégis találó a magyar földtani kutatás perspektívájából. Tenger híján a Balaton a legnagyobb vizes üledékgyújtőnk, amelyben folyamatukban vizsgálhatók olyan geológiai és geokémiai jelenségek, mint - sok egyéb mellett - a karbonátképződés, biogén ásványkiválás, üledékáthalmozás, ásványok és mikroorganizmusok, üledék és tápanyagok, illetve üledék és éghajlatváltozás kapcsolatai. Nem meglepő, hogy nagy tudósaink szívesen foglalkoztak a Balatonnal vagy a környékével, könyvtárnyi irodalmat hagyva maguk után (LóczY 1913). Sok esetben új módszerek tökéletesítésére is a Balaton nyújtott megfelelố természeti hátteret vagy kutatási célt Eötvös Loránd ingájá- 

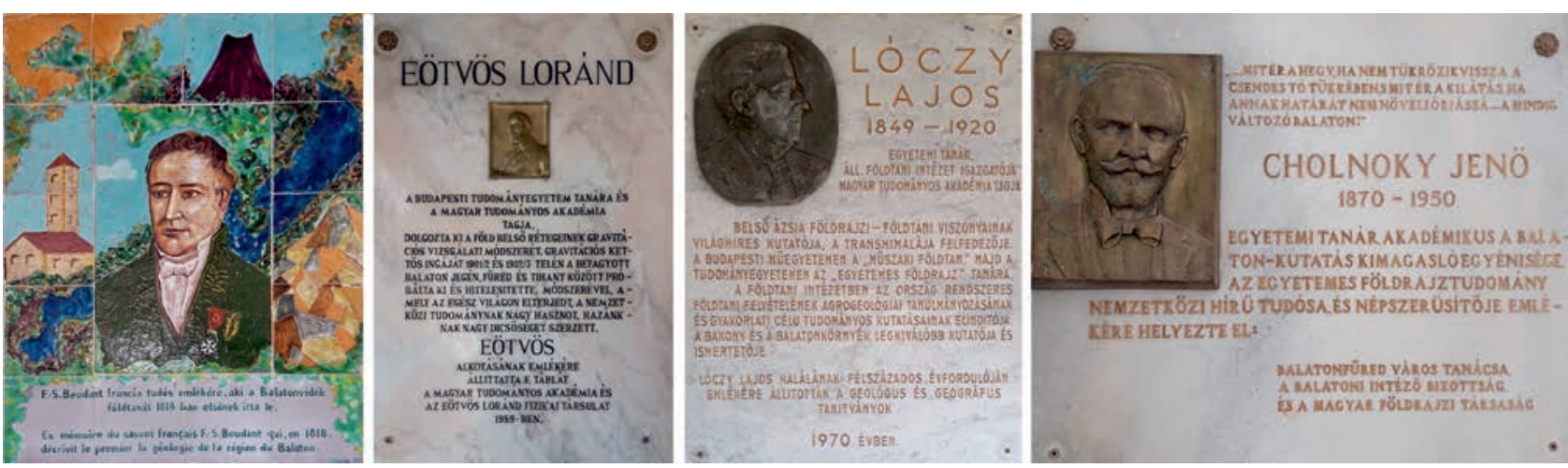

1. ábra. Francois-Sulpice BEUDANT, EÖTvös Loránd, Lóczy Lajos és CHOLNOKY Jenő emléktáblája a „Balatonfüredi Pantheon” falán

Figure 1. Plaques on the walls of the "Balatonfüred Pantheon”, commemorating famous scientists: Francois-Sulpice BEUDANT, Loránd EÖTVÖS, Lajos LócZY and Jenö CHOLNOKY

tól (SZABó \& BODOKY 2019) a legutóbbi vízi szeizmikus mérésekig (Tóth et al. 2010, VISNOviTZ et al. 2019). Neves elődeink nemcsak szúk szakmai körben ismertek, hanem máig - joggal - valóságos kultusz is övezi munkásságukat: oktatási és kutatási intézmények, utcák és emléktáblák ôrzik nevüket (1. ábra). A Balaton kutatására kezdettől jellemző volt az inter- és multidiszciplinaritás, amely nemcsak intézmények, hanem különböző tudományágakat múvelô szakemberek közötti hosszútávú, sikeres együttmúködések révén valósult meg. A tihanyi intézet (mai nevén Ökológiai Kutatóközpont, Balatoni Limnológiai Intézet) hidrobiológusainak, a VITUKI mérnökeinek, a MÁFI geológusainak, a MÁELGI és az ELTE geofizikusainak és sok más intézet kutatóinak közös munkája vezetett a legérdekesebb tudományos eredményekre.

A Földtani Közlöny 150 évvel ezelőtti születése nagyjából egybeesik a Balaton és környéke tudományos vizsgálatának kezdetével. A kutatás intenzitása periodikusan változott, és az egyes ciklusokat általában összefoglaló tanulmányok zárták le, kezdve a híres Lóczy-féle sorozattal („A Balaton tudományos tanulmányozásának eredményei”; LóczY 1913), bezárva a Magyarhoni Földtani Társulat kiadásában épp megjelent, ismeretterjesztô célzatú Lóczy-emlékkötettel (BABINSZKI \& HoRVÁTH 2020). A jelen írásnak nem célja mindezen kutatások eredményeinek áttekintése. Így nem térünk ki sem a Balaton-felvidék földtanával (BUDAI \& Csillag 1998), sem a tó hidrobiológiájával foglalkozó óriási irodalomra (pl. ENTZ \& SEBESTYÉn 1942). Kizárólag a Balaton holocén üledékével, azon belül is ennek ásványtani vonatkozásaival foglalkozunk, elsôsorban a jelenleg is zajló kutatások fő irányait felvázolva.

Az iszap több évtizedes kutatását az alapvető tudományos kíváncsiságon túl néhány speciális, konkrét cél motiválta: (1) a tó fejlődéstörténetének tisztázása (CSERNY et al. 1991a), (2) a holocén éghajlatváltozások vizsgálata (CSERNY 2002, SÜMEGI et al. 2008), (3) a tó üledékfelhalmozódása miatti aggodalom (SZESZTAY 1966), valamint (4) az üledék szerepének megértése a tó tápanyagforgalmában, ezáltal eutrofizációjában (SOMLYÓDY \& VAN STRATEN 1986). E célokat tekintve a balatoni iszap vizsgálata sok szempontból sikertörténet. Meglehetôs pontossággal ismerjük a tó keletkezésé- nek idejét, kialakulásának fázisait, az iszap felhalmozódásának ütemét (CSERNy 2002, TULLNER 2002). Paleontológiai (NAGyné Bodor \& Szurominé KoreCZ 2002, BuCZKó et al. 2005) és izotópgeokémiai (CSERNY et al. 1995, SCHÖLL-BARNA et al. 2012) vizsgálatok készültek az éghajlatváltozások elemzésére. A legnagyobb sikernek azonban az eutrofizáció megfékezése tekinthető: a tudományos kutatások eredményeire (SOMLYódy \& VAN STRATEN 1986, HERODEK \& ISTVÁNOVICS 1986, IsTVÁNOVICS et al. 1989) alapozva készültek el a 20. század végére azok a vízügyi és vízminőség-védelmi beavatkozások, amelyeknek általában mind a szakma, mind a közvélemény a Balaton utóbbi két évtizedben tapasztalt kiváló vízminôségét tulajdonítja.

Mindezek ellenére a fenti kutatási témák ma is aktuálisak. Ennek oka egyrészt a vizsgálati módszerek rohamos fejlődése, amelynek révén a korábbiaknál mindig pontosabb és részletesebb adatok nyerhetők az iszap mennyiségéről, koráról, anyagáról, az élővilággal való kölcsönhatásairól (PóSFAI et al. 2019a). De a balatoni iszap mai kutatásának van egy fontosabb ösztönzője: az 1994-et követő „,békeidő” után először 2019-ben tapasztalt algavirágzás. Az idei nyáron (2020-ban) már a napi hírek között is rendszeresen jelennek meg a Balaton vizérôl és planktoni kékalgáiról szóló tudósítások, amelyek hol vészharangot kongatnak, hol nyugtatják a közvéleményt. Valójában nem tudjuk, mi okozta a 2019-es és a kisebb 2020-as virágzásokat, és azt sem, hogy várhatók-e hasonló események a jövőben. Annyi biztosnak túnik, hogy az algák számára nélkülözhetetlen tápanyagok - elsősorban a foszfor - az iszapból szabadulhattak fel (IsTVÁNOVICS et al., közlésre benyújtva). Nemcsak a planktonikus algák okoztak mostanában riadalmat, hanem a fenéken élő, bevonatot alkotó szervezetek is: 2020 tavaszán Balatonalmádi strandján a vízfelszínt az üledékről felszakadt algagyepdarabok borították (2. ábra). Ezek a témák jól illusztrálják, hogy a Balaton iszapját, az iszap tápanyagforgalomban betöltött szerepét még mindig nem ismerjük eléggé, és az iszap ásványainak kutatása nemcsak szakmai kíváncsiságunk kielégítését szolgálja, hanem rendkívül fontos a tó (számunkra) kedvező állapotának megőrzése érdekében is.

A balatoni iszap vizsgálatának tehát új lendületet adott a sajnálatos vízminőségromlás, és a kutatás jelenleg is nagy 


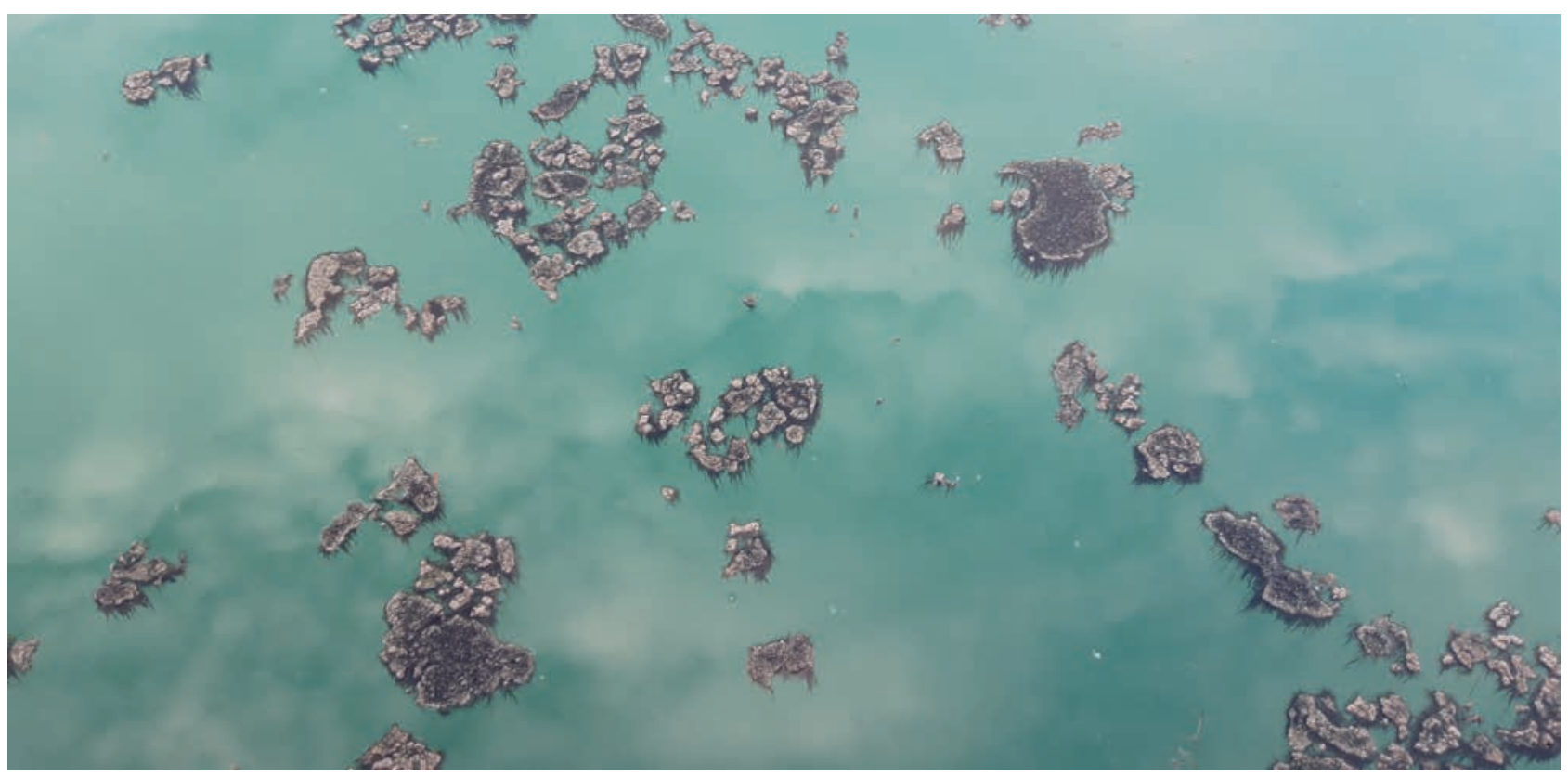

2. ábra. Az iszap felszínéről felszakadt algaszőnyegdarabok Balatonalmádi kikötőjében, 2020. május 23-án. (A világos foltok a vízben tükröződő felhők.)

Figure 2. Pieces of algal mats released form the sediment surface, floating on the water in the harbor of Balatonalmádi on 23rd May, 2020. (The whitish areas are reflections of clouds.)

intenzitással folyik. Sok új eredmény vár még feldolgozásra és publikálásra, amelyekről ebben az összefoglaló tanulmányban legfeljebb csak érintőlegesen lehet szó. Az alábbiakban az üledék kutatástörténetének vázlatos áttekintése után tárgyaljuk a tóban lezajló ásványképző folyamatokat, az ezekkel kapcsolatos aktuális kérdéseket, utalva a jelenleg is folyamatban lévő kutatásokra.

\section{Mennyi az iszap? Kutatástörténeti áttekintés}

A Balaton kutatásának kezdeteitôl az egyik fő cél a tó korának megállapítása volt, ehhez pedig a nyilvánvaló kulcsot az üledék adja. Ezért az üledék vastagságának meghatározása már id. Lóczy Lajos idejében is alapvető kérdés volt. Lóczy hajóról több fúrást mélyített a tó aljzatába az akkori technológia szerinti legmodernebb eszközökkel. A következő fúrásokat 1948-ban mélyítették (ZóLYOMI 1952), majd az 1960-as években egy újabb sorozatot a VITUKI kutatói (SzESZTAY 1966). A modern, 20. századi geokémiai módszerek alkalmazását hozták el az 1970-es évek, amikor German MüLLER heidelbergi kutató vezetésével újabb hat fúrással harántolták a holocén iszapot. Az ásványtani szempontból máig alapmúnek tekinthető 1978-as munkájukban (MÜLLER \& WAGNER 1978) írták le először világosan, hogy az iszap felét-kétharmadát a tóban képződő karbonátásványok adják. Az iszap felsô $10 \mathrm{~cm}$-ének alapvetô tulajdonságait (szemcseszerkezet, karbonáttartalom, szervesszén-, nitrogén- és oldhatófoszfor-tartalom) 5000 minta alapján MÁTÉ (1987) térképezte fel.

A Balaton üledékének kutatásában a legintenzívebb és legeredményesebb fázist a MÁFI által, CSERNY Tibor veze- tésével végzett kutatás képviselte. 1981-tôl kezdődően 33 magfúrással és 373 fkm-nyi geofizikai szelvénnyel az egész tó területén feltérképezték a laza üledék vastagságát. A fúrások anyagát sokoldalúan, szedimentológiai, ásványtani, geokémiai és palinológiai vizsgálatokkal feldolgozták (CSERNY 2002). Ezek a vizsgálatok alapozták meg a tó kialakulására és fejlődésére vonatkozó megállapításokat (3. ábra), amelyekkel azóta is - nemcsak a szakirodalomban, hanem az ismeretterjesztő médiában és a nemzeti park tájékoztató tábláin is - számtalan helyen találkozhatunk. Szintén CsERNy Tibor kezdeményezésére kubai szakemberek végezték az első vízi szeizmikus méréseket a Balatonon, ezek eredményeként elkészült egy újabb, a korábbinál pontosabb iszapvastagságtérkép (CSERNY \& CORRADA 1990). Megállapították, hogy az idősebb pleisztocén és pannóniai korú rétegekre diszkordánsan települő holocén iszap vastagsága átlagosan $5 \mathrm{~m}$ körüli, de helytől függốen 0 és 9 m között változik. A felsô, néhány cm-es réteg anyaga könnyen felkavarodik, és az áramlások áthalmozhatják - így fordulhat elő, hogy az állandó, erős áramlásnak kitett Tihanyi-szorosban alig van üledék, míg a tóközépi részeken 6-7 m, a Zala torkolatában pedig $10 \mathrm{~m}$ vastagságot is elérhet (4. ábra).

A vízi szeizmikus mérések új lendületet kaptak a 2000es években (CSERNY et al. 2005) és jelenleg is zajlanak az ELTE geofizikusai koordinálásában (ZLINSZKY et al. 2010; VISNOVITZ et al. 2017, 2019). Az egyre fejlettebb eszközök és sûrúbb szelvények által mind precízebbé váló mérések eredményeként minden eddiginél pontosabb adataink vannak az iszapmélységrôl, és a korábbi mérésekkel összehasonlítva az iszap áthalmozódásáról, dinamikájáról is fogalmat alkothatunk (KISS et al. 2018).

Nemcsak az iszapvastagság, hanem a szemcseméret is 

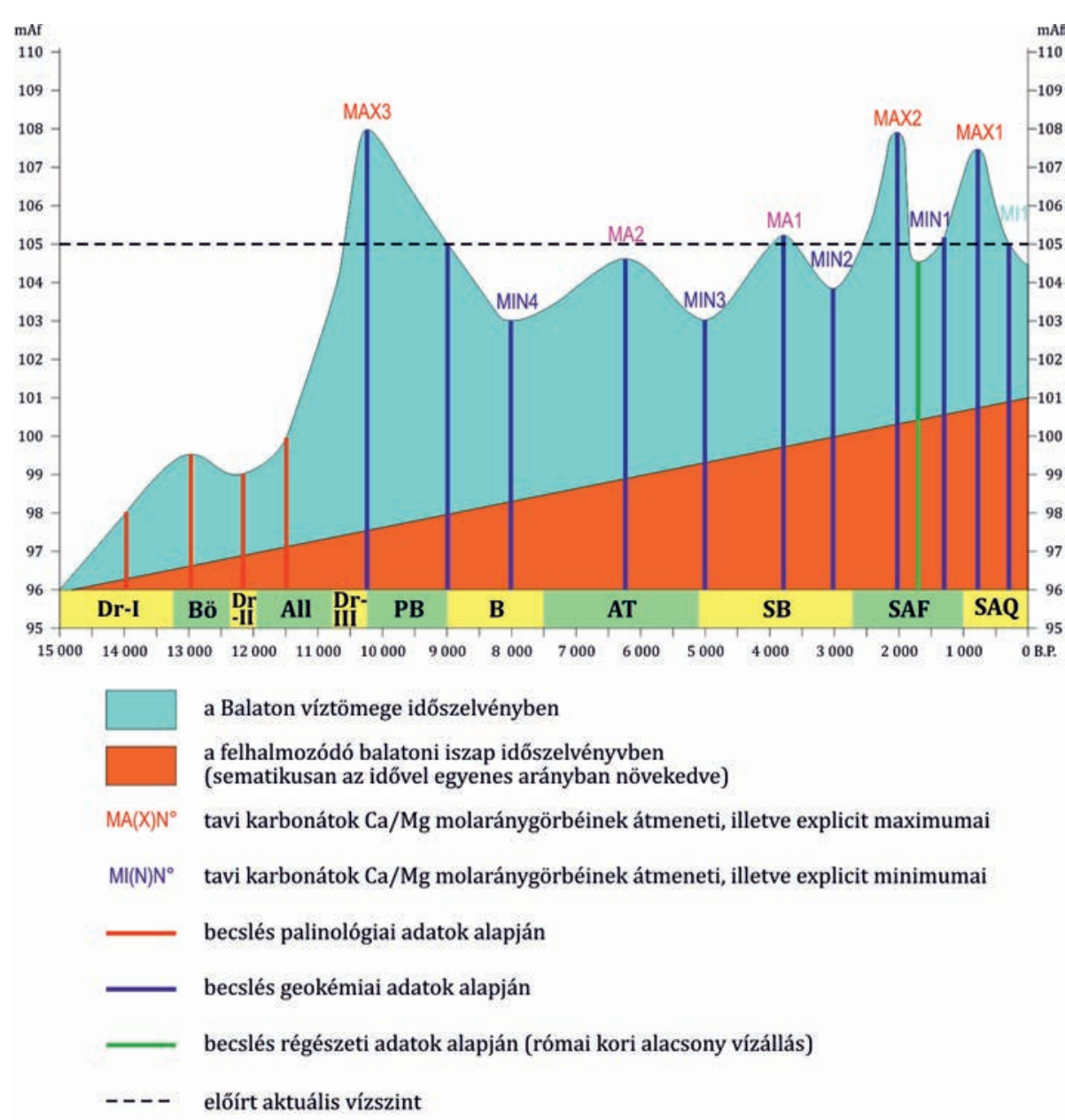

Dr-I, Bö, Dr-II, All, Dr-III felsố-pleisztocén, posztglaciális időszakok

3. ábra. A Balaton vízszintjének változásai és iszapjának felhalmozódása paleontológiai, geokémiai és régészeti adatok alapján, Tullner (2002) és Tullner \& CSERNY (2003) nyomán. (Bár az iszapfelhalmozódás üteme valószínűleg nem volt egyenletes, megfelelő adatok hiján az ábra így ábrázolja.)

Figure 3. Changes in water level and the accumulation of bottom sediment in Lake Balaton, according to paleontological, geochemical and archaeological data, based on TULLNER (2002) and TULLNER \& CSERNY(2003). (In lack of appropriate data the rate of sediment accumulation is shown as uniform, even though it likely changed over time.)

jellegzetes változatosságot mutat (CSERNY 2002). Még a laikus fürdőzők számára is jól ismert tény, hogy az uralkodó északi szelek a déli part mentén egy néhány száz m széles homokzátonyt alakítottak ki, míg az északi part mentén és a tó

nyagot Mai tudásunk tükrében abnormálisann nagy étéket kapott (Lóczy 1920, in: VIRÁG 1998). Később, az 1930-as évektől parázs vita bontakozott ki arról, mennyiben járul hozzá a befolyó vizek, elsősorban a Zala hordaléka az iszaphoz.

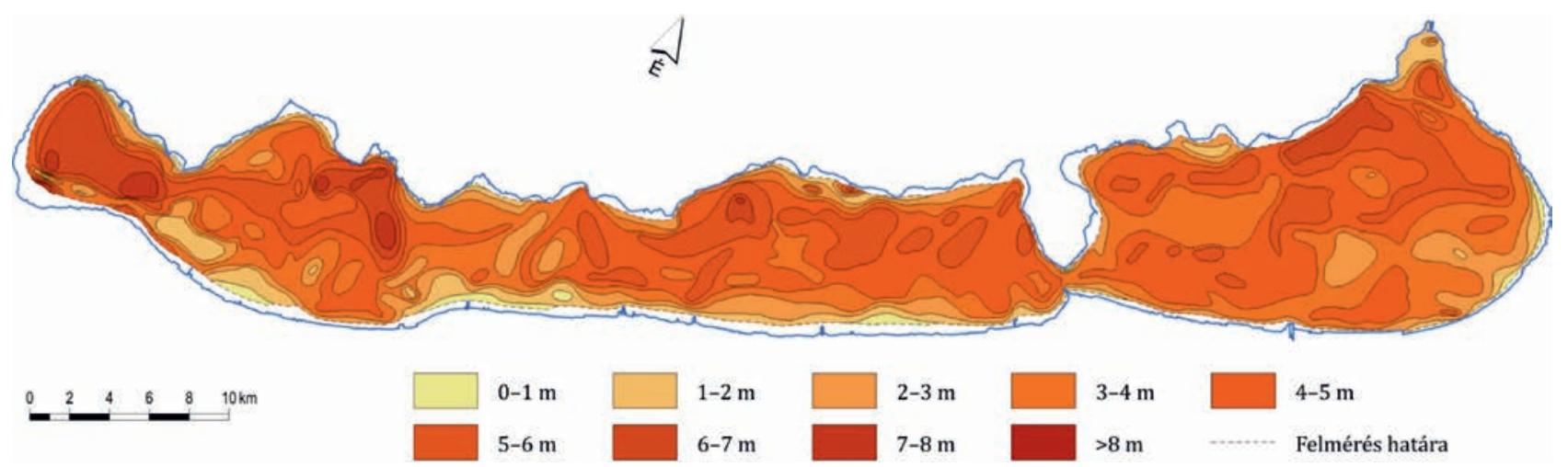

4. ábra. A Balaton holocén iszapjának vastagsági térképe (CSERNY 2002 nyomán)

Figure 4. Thickness map of the Holocene sediment in Lake Balaton (according to CSERNY 2002) 
Egészen szélsőséges becslések is megjelentek az irodalomban (VIRÁG 1998), míg a század második felében pontosabb mérésekkel megállapították, hogy a hulló por és a befolyók hordaléka azonos nagyságrendú anyaggal járul az iszaphoz (SZESZTAY 1961). Felmerült, hogy a biogén szerves anyag az üledék fő alkotója, azonban hamarosan tisztázódott, hogy az elpusztult szervezetek anyaga a Balatonban gyorsan lebomlik, és a szerves anyag még az iszap felső $10 \mathrm{~cm}$-ében is legfeljebb az iszap 1-5 tömeg\%-át teszi ki (MÁTÉ 1987). SzESZTAY (1966) számításaiban már a befolyókkal beérkező oldott ionokból kicsapódó karbonátot tekintette az iszap fő komponensének, majd MülLER \& WAGNER (1978) tisztázta, hogy a Balaton 15 ezer éves történetében a vízből kiváló karbonátok uralták az üledékképződést. Ezt a képet tovább finomították a CSERNY Tibor vezette vizsgálatok (CSERNY et al. 2020), különösen a Mg-tartalmú kalcit képződésére vonatkozóan (TULLNER 2002, CSERNY et al. 1991b).

Felmerülhet a kérdés, miért volt szükség több évtizedre annak megértéséhez, hogy az iszap kb. kétharmada autochton ásvány. A válasz egyszerú: a Balaton iszapjában nincs semmi különös, épp azok a „közönséges” ásványok alkotják - karbonátok, kőzetalkotó szilikátok - amelyek a hulló porral, a befolyók által szállított hordalékkal vagy a partelhabolás révén is érkeznek. A Tapolca-patak által szállított triász kalcitszemcse, a Szaharából érkező porban lévő kalcit és a Balatonban kicsapódó kalcit között első közelítésben nem látunk különbséget: mindhárom kalcit. Ha azonban részletesebben megvizsgáljuk a szemcseméret és -morfológia, az összetétel (elsősorban a Mg-tartalom) és esetleg a kristályszerkezet összefüggéseit, akkor kirajzolódnak a kalcit és kalcit közötti különbségek, és nemcsak a kalcit eredetére, hanem a tavi karbonátképződés sok apró részletére is fény derül (TOMPA et al. 2014, NYIRÓ-KósA et al. 2018; FODOR et al. 2020). Az iszap különböző eredetú alkotóelemeinek azonosítását, arányaik pontosabb becslését célozza egy jelenleg is folyó kutatás (RostÁsI et al. 2020). Az előzetes eredmények nagyjából alátámasztották az ismert arányokat a légköri ülepedésre és befolyók által szállított anyagra vonatkozóan, azonban a tavi kalcitkicsapódás esetében a korábbiaknál jelentősen nagyobb értéket adtak (RosTÁsı et al. 2019). Az eltérésnek sok oka lehet, de ezeket korai lenne a jelen közleményben tárgyalni.

Az allochton, általában nagyobb szemcseméretú ásványok tehát beérkeznek a Balatonba, leülepednek, időnként felkavarodnak és áthalmozódnak, majd nagyrészt eltemetôdnek az iszapban (egy elhanyagolható hányaduk távozik a Sión). Ezekkel az ásványokkal a továbbiakban nem foglalkozunk. Bár fontosak a Balaton vízminősége szempontjából, az üledék antropogén eredetú fémes és szerves szennyezőit (MÜLLER 1981, HLAVAY \& POLYÁK 2002) sem tárgyaljuk részletesen. Ásványtani szempontból kétségkívül a legérdekesebb frakció az autochton ásványoké, és jelenlegi tudásunk szerint ezek játszanak szerepet a tápanyagok, elsôsorban a foszfor megkötését és felszabadítását eredményező folyamatokban. Ezért a továbbiakban a tóban képződő ásványokról lesz szó.

A Balaton vizében és üledékében lezajló ásványképző- désben - még ha többnyire közvetve is - biológiai folyamatok játszanak fontos szerepet. Jellege szerint a bioásványképződést általában két nagy csoportra osztja a szakirodalom: a „biológiailag indukált" (biologically-induced mineralization, BIM) és „biológiailag szabályozott” (biologically-controlled mineralization, BCM) módokra (PósFAI \& DuNiN-BorkowsKi 2006). A BIM esetében az élőlények hatása elsôsorban a vízkémia szabályozásában, finomhangolásában mutatkozik meg (pl. a fotoszintézis vagy az elpusztult szervezetek bomlása révén). Az ásványkiválás tehát az életmúködés közvetett következményeként, az általa okozott kémiai változások miatt következik be. Szintén a BIM kategóriába sorolhatók azok a folyamatok, melyek során az élőlény felszíne passzívan elősegíti a kristálycsírák képződését, mivel heterogén nukleációs felületet biztosít az oldatban. A BCM kategóriába tartoznak azok a folyamatok, melyek során az élőlény aktívan, valamely életfunkciójának betöltése céljából választ ki ásványt. Ezekben az esetekben a képződő ásvány fizikai és kémiai tulajdonságai szigorúan szabályozottak, mint ahogy például a balatoni kagylóhéjak és kovaalgavázak példája is mutatja. Az alábbiakban a Balaton iszapja szempontjából fontosnak tekinthető, biológiailag indukált, illetve szabályozott módon képződő ásványok jellegzetességeit és jelentőségét tárgyaljuk.

\section{Karbonátásványok biológiailag indukált képzódése heterogén felületen}

A Balaton rendkívül sekély (+115cm vízállásnál átlagosan 3,55 m mély), hidrogénkarbonátos-meszes tó, amelynek vizére jellemző a 8,5 körüli pH, valamint a nagy (1 és 4 között változó) oldott $\mathrm{Mg} / \mathrm{Ca}$ mólarány (lásd például ToMPA et al. 2014). Ilyen vízkémia mellett mind a dolomitra, mind a kalcitra nézve túltelített az oldat, tehát kiválásuk termodinamikailag szükségszerü lenne (5. ábra). Mint az jól ismert, a dolomit közvetlen kiválása kinetikailag gátolt (GREGG et al. 2015, HAAs \& HIPS 2020), a kalcit kicsapódását pedig a jelenlévő, inhibitorként ismert Mg akadályozhatja (Sun et al. 2015). Ezért tehát, bár a víz nincs kémiailag egyensúlyban, a karbonátok kicsapódásához további „,segítségre” van szükség - ezt biztosítja a fotoszintézis és a heterogén nukleáció.

A fotoszintézis szerepe miatt tekinthetjük a balatoni karbonátkiválást BIM folyamatnak. Mind a plankton, mind az üledékfelszínt borító bevonatlakó algák hozzájárulnak ahhoz (a szél okozta átkeveredés mellett), hogy a Balatonban jellemzően az egész vízoszlopban van oldott oxigén, és a pH az említett 8,5 körüli. Nagy elsődleges termelés, pl. algavirágzás esetén lokálisan megnövekedhet a $\mathrm{pH}$, ami intenzív kalcitkiválást, fehér csóvák megjelenését eredményezheti a vízben. Ez a whitening néven emlegetett jelenség jól ismert a Balatonnál nagyobb tavakban, sôt az óceánokban is (Thompson et al. 1997). A Balatonon olykor nemcsak csóvákban jelenik meg a fehéredés, hanem - különösen tavaszszal - szinte az egész víztestre jellemző a „tejfölösség”, köszönhetően a karbonátok kicsapódásának (6. ábra).

A karbonátok kiválását azonban nemcsak a vízkémia, 

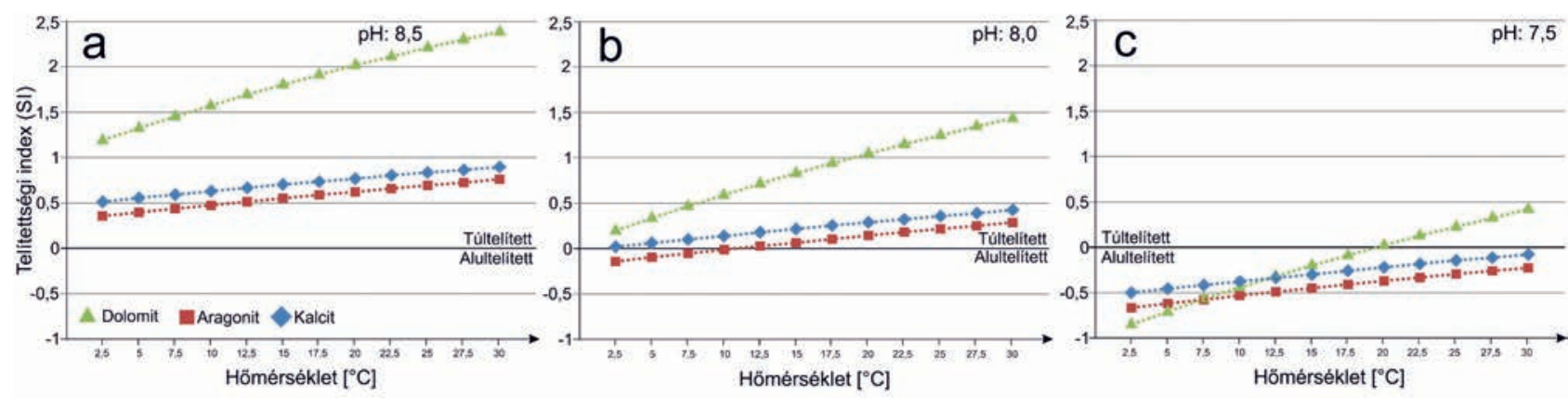

5. ábra. A telítettségi index változása a hőmérséklet függvényében, három különböző pH-érték mellett a dolomit, kalcit és aragonit ásványokra a Balaton vízkémiai viszonyai között. (a) és (b) inkább a nyílt vízre, míg (c) az üledékre jellemző. (MolNÁR Zsombor számításai alapján.)

Figure 5. Variation in saturation indices of the carbonate minerals dolomite, calcite and aragonite as a function of temperature, at three different pH values, under water chemical conditions typical for Lake Balaton. (a) and (b) show conditions that are characteristic for the open water, whereas (c) is representative of the sediment. (Calculations by Zsombor MOLNÁR.)

hanem a már jelenlévő egyéb szilárd anyagok, a Balaton esetében elsősorban az agyagásványok is befolyásolják. Az agyagásványok szerepének megértése érdekében ki kell tekintenünk egy jelenleg rendkívül intenzíven vizsgált alapkutatási téma, a kristálycsíra-képződés problémájára. A „klasszikus nukleációs elmélet” értelmében az oldat ionjaiból és molekuláiból folyamatosan képződnek és visszaoldódnak csírák mindaddig, amíg a statisztikus fluktuációk nem eredményeznek egy kritikus méretnél nagyobb magot, amely már spontán növekedni képes az egyedi ionok vagy molekulák (monomerek) hozzáadódásával (Sosso et al. 2016). Ezzel szemben az újabb, ,nem klasszikus” elméletek szerint az oldatban eleve vannak termodinamikailag stabil ion-asszociációk (klaszterek), és ezek aggregálódása eredményezi az elsô kristálycsírákat (GEBAUER et al. 2018). Mindkét esetben nagy jelentősége van, hogy az oldat telje- sen homogén (azaz csak a csíraképző anyagok vannak jelen) vagy heterogén (azaz jelen van valamilyen más szilárd felület): a csíraképződés aktivációs energiáját (vagy másképpen a kritikus méretet) csökkenti, ha a monomerek vagy klaszterek egy meglévő felületen megkötődhetnek (Hu et al. 2012).

A világ nagy tavaiban több helyen megfigyelték, hogy a karbonátok kristálycsírái a planktoni kékalgák felületén válnak ki (DiTTRICH \& OBST 2004). Érthető, hiszen a feljebb említett vízkémiai változás is a fotoszintetizáló szervezetek közelében a legkifejezettebb, egyúttal a sejtfelszín kiváló heterogén nukleációs felület. Ezzel szemben a Balaton iszapját alkotó kalcit esetében nem karbonát/kékalga, hanem kalcit/szmektit aggregátumokat találtunk (NYIRŐ-KósA et al. 2018) (7. és 8. ábra). A Balaton egyik különleges tulajdonsága a sekélysége, aminek következtében még enyhe szelek is felkavarhatják az üledékét. A legfinomabb, tipikusan csak

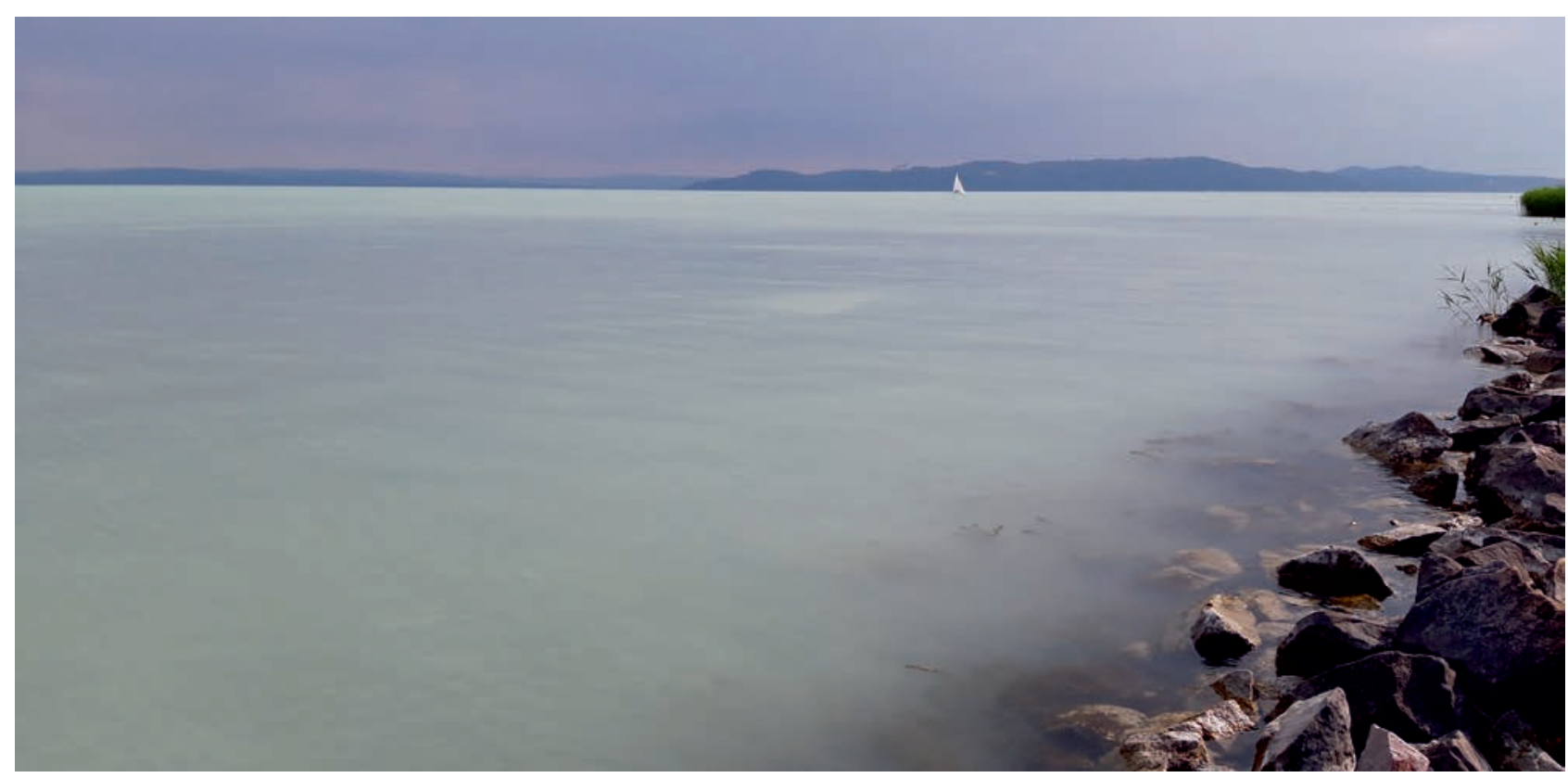

6. ábra. Intenzív karbonátkicsapódás miatti „fehéredés” a Balaton vizében, 2020. május 15-én

Figure 6. "Whitening" in the water of Lake Balaton on 15th May 2020, as a result of intense carbonate precipitation 


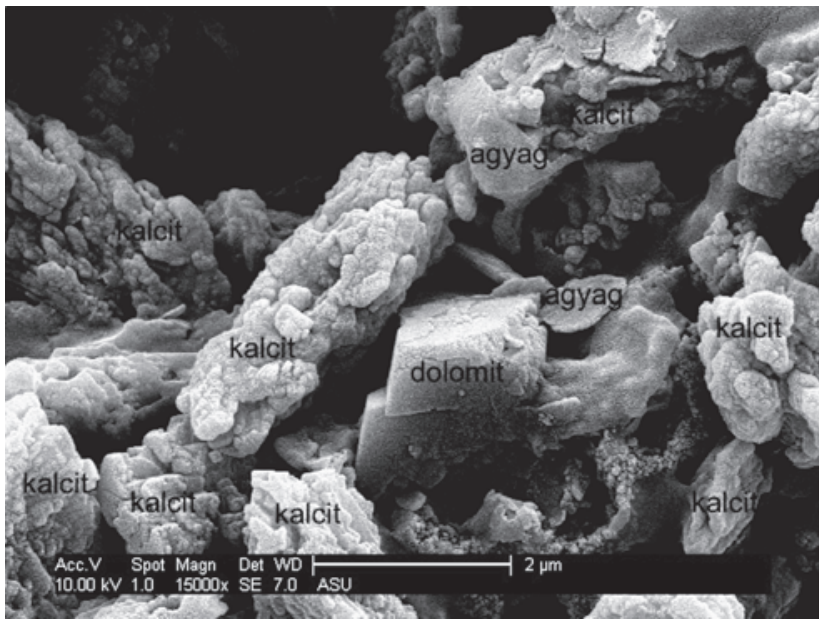

7. ábra. Tipikus balatoni üledék pásztázó elektronmikroszkópos (SEM-) felvétele: hosszúkás, aggregátumszerủ Mg-tartalmú kalcitszemcsék, egy saját alakú dolomitszemcse és néhány, jellemzően a karbonátokra tapadó agyagásványlemez

Figure 7. Scanning electron microscopy (SEM) image of typical bottom sediment from Lake Balaton: elongated, aggregate-looking grains of calcite ("kalcit"), a euhedral grain of dolomite ("dolomit"), and flakes of clay minerals ("agyag", typically attached to the carbonates

néhány atomi réteg vastagságú szmektitszemcsék - vagy inkább nanofoszlányoknak lehet nevezni ezeket - szinte soha nem tudnak leülepedni, a vízoszlopban mindig megtalálhatók. Negatív töltésú felületük kiválóan alkalmas lehet arra, hogy a pozitív töltésú ionokat vagy ionklasztereket
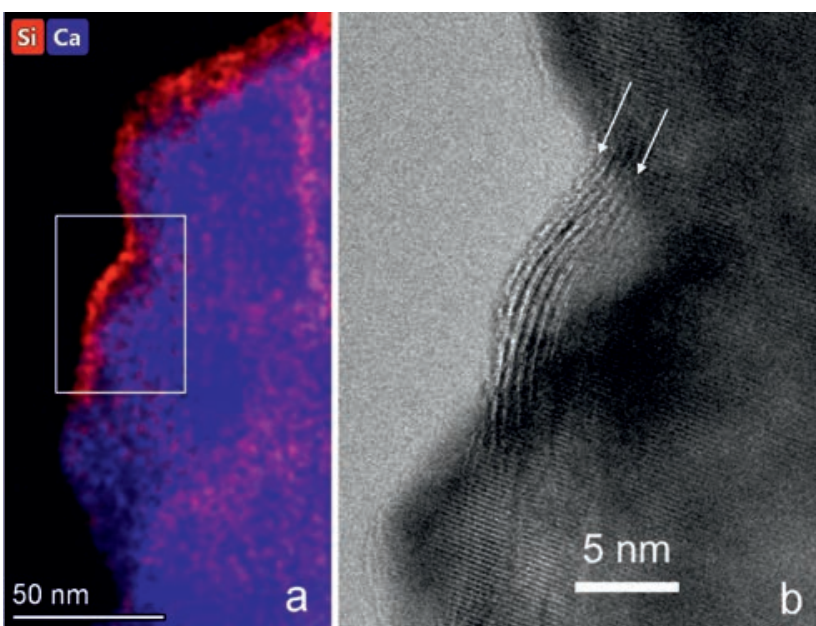

8. ábra. Mg-tartalmú kalcit és szmektit agyagásvány szoros kapcsolata. (a) Pásztázó transzmissziós elektronmikroszkópos (STEM-) módban, energiadiszperzív röntgenspektrometria (EDS) alkalmazásával készült elemtérkép, amelyen a Ca és a Si eloszlása mutatja a kalcitkristály, illetve a „szmektitleplek” kapcsolatát. (b) Nagy felbontású TEM-(HRTEM-) felvétel az (a) ábrán fehér téglalappal jelölt területről. A fehér nyilak egy néhány elemi réteg vastagságú szmektitleplet jelölnek. Mind a szmektit, mind a kalcit rácssíkjai láthatók

Figure 8. Transmission electron microscopy (TEM) results illustrating the tight association of Mg-bearing calcite with smectite. (a) Elemental map obtained using energy-dispersive X-ray spectrometry in scanning transmission (STEM) mode, showing the distributions of $\mathrm{Ca}$ (in calcite) and $\mathrm{Si}$ (in smectite). (b) High-resolution TEM image of the boxed area in (a); the white arrows mark a smectite flake with a thickness of a few atomic layers. Lattice fringes of both calcite and smectite are visible megkösse, ezzel beindítva a kristályképződést. A Balatonban megfigyelt kalcit/szmektit aggregátumok azonban elvileg úgy is képződhettek, hogy a már kialakult kalcitcsírák koaguláltak a vízben lebegő szmektitpelyhekkel. Ezért laboratóriumi kísérleteket és elméleti számításokat is végeztünk, hogy megértsük, a kétféle lehetôség közül - kristálynukleáció a szmektiten vagy koaguláció - melyik valószínúbb.

Molekuladinamikai számításokkal modelleztük a Balaton vizéhez hasonló összetételű oldatban a kristálycsírák képződését (FODOR et al. 2020), összehasonlítva a homogén oldatban lejátszódó klaszterképződést a kaolinit és a szmektit két-két elemi rétege közötti oldatban zajló folyamatokkal (9. ábra). Mindhárom rendszerben úgy találtuk, hogy az ionklaszterek nem az agyag felületén, hanem elsôsorban az oldatban képződnek, ami a fent említett, „,nem klasszikus” kristálycsíra-képződésre utal. Az oldatban létrejött klasztereket azonban a szmektit nagy hatékonysággal „,befogja” (szemben a kaolinittel), azaz a klaszterek a két agyagréteg közötti térből a szmektit felületére migrálnak és azon adszorbeálódnak. Laboratóriumi kísérleteink (MoLNÁR et al. 2020a) az elméleti számításoknál még látványosabban igazolták a szmektit szerepét a kristálycsíra-képződésben (10. ábra). Karbonátos oldathoz $\mathrm{Ca}^{2+}$-ionokat tartalmazó oldatot adagolva a $\mathrm{Ca}^{2+}$-koncentráció hirtelen esése jelzi a kristálycsíraképződés pillanatát. A homogén oldathoz képest ez a pillanat szmektit jelenlétében hamarabb, azaz kisebb menynyiségú hozzáadott $\mathrm{Ca}^{2+}$ és kisebb $\mathrm{Ca}^{2+}$-aktivitás mellett következik be. Minél több agyag van a rendszerben, a nukleáció annál korábban következik be. Tehát a balatoni karbo-

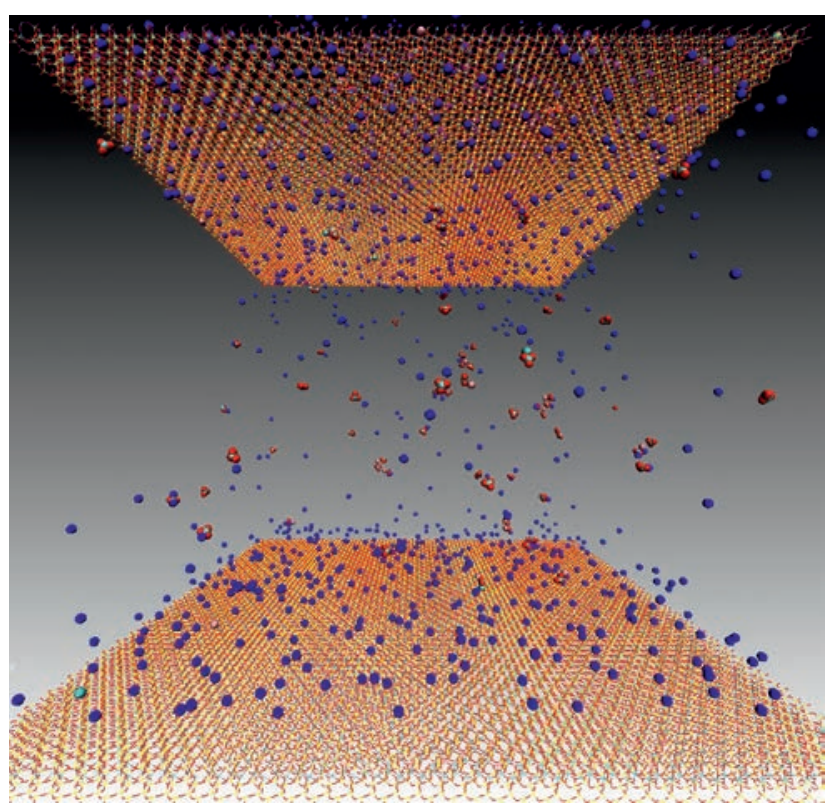

9. ábra. Pillanatfelvétel egy molekuladinamikai szimulációról, két montmorillonitréteg között a Balatonéhoz hasonló összetételủ oldatban kialakuló ionklaszterekröl, 30 ns után $\left(\mathrm{CO}_{3}^{2-}\right.$ : piros, $\mathrm{Mg}^{2+}$ : zöld, $\mathrm{Ca}^{2+}$ : mályva, $\mathrm{Na}^{+}$: kék; a vízmolekulák nincsenek feltüntetve)

Figure 9. Snapshot from a molecular dynamics simulation of ion cluster formation after $30 \mathrm{~ns}$ in a solution that approximately represents lakewater composition, enclosed between two montmorillonite layers $\left(\left(\mathrm{CO}_{3}{ }^{2-}: \mathrm{red}, \mathrm{Mg}^{2+}\right.\right.$ : green, $\mathrm{Ca}^{2+}$ : pink $\mathrm{Na}^{+}$: blue; water molecules are not shown) 


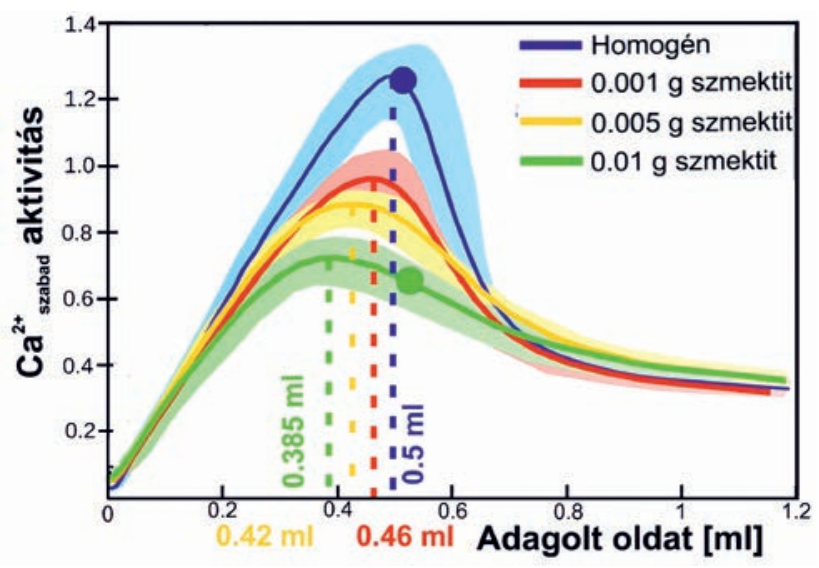

10. ábra. Kalcium-karbonát képződés homogén oldatban és szmektit agyagásvány jelenlétében (a heterogén kísérleteket három különböző agyagmennyiséggel végeztük). A kísérlet során karbonátionokat tartalmazó oldatot titráltunk $\mathrm{Ca}^{2+}$-ionokat tartalmazó oldattal. Szmektit jelenlétében a kristálycsíraképződés korábban megtörténik, mint homogén oldatban. (A színes sávok a kísérletek szórását jelzik, a kék és zöld kör a TEM-vizsgálatokhoz történt mintavétel helyét.)

Figure 10. Calcium carbonate formation in titration experiments in a homogeneous solution (blue curve) and in the presence of three different amounts of smectite (red, yellow and green curves, in the order of increasing amounts). In the experiments a solution containing carbonate ions was titrated with $\mathrm{Ca}^{2+}$-bearing solution. In the presence of smectite nucleation takes place earlier (at a lower amont of dosed solution, as shown on the horizontal axis) than in the homogeneous solution, as indicated by the drop in the $\mathrm{Ca}^{2+}$ activity (vertical axis). (The colored bands mark the scatter in three experiments, whereas the blue and green dots indicate the positions where samples were taken for TEM studies.)

nátképződés egyik érdekessége, hogy míg a kalcit kicsapódásához szükséges termodinamikai hajtóerőt egy biológiai folyamat, a fotoszintézis biztosítja, a kristálycsíra-képződés energiagátjának átlépését egy - feltehetően allochton - ásvány, a szmektit nanométeres pelyhei segítik.

\section{A kicsapódó karbonátok összetétele és ásványfázisa}

A Balaton különlegességei közé tartozik - sekélysége mellett - a víz nagy oldott $\mathrm{Mg} / \mathrm{Ca}$ mólaránya, és ennek nyugat-kelet irányú változása. Mivel a Zala hozza a beérkező víz legalább felét, és a többi jelentôsebb hozamú befolyó (Nyugati-övcsatorna és Tapolca-patak) torkolata is a tó nyugat végén van, az egyetlen kifolyó, a Sió-csatorna pedig a keleti végén hagyja el a tavat, a Balatonra nyugat-kelet irányú kémiai gradiensek jellemzők. A feljebb részletezett kalcitkiválás során kis Mg-tartalmú kalcit csapódik ki (7. ábra), ezért nyugatról kelet felé haladva az oldott Mg relatív mennyisége nô a Ca-hoz képest. Ezenkívül a keleti tómedencébe folyó kisebb patakok a dolomitos lehordási területükről Mg-ban dús vizet szállítanak a tóba. Ennek megfelelően előfordulhat, hogy Keszthelynél az oldott Mg/Ca mólaránya kb. 1, ugyanekkor Balatonkenesénél 3,5 (TompA et al. 2014). Ez a Ny-K irányú vízkémiai gradiens a kicsapódó karbonát összetételére is hat: míg Keszthelynél a lebegő anyagban lévő kalcit átlagos $\mathrm{MgCO}_{3}$-tartalma 2,5 mol\% körüli, Balatonkenesénél 8\%-ot is elérhet (NYIRÓ-KóSA et al. 2018).
A kalcit Mg-tartalmának környezetjelző szerepére már Müller \& WAGNER (1978) is felhívta a figyelmet, majd CSERNY et al. (1991b) és TULLNER (2002) dolgozta fel részletesen az iszapban lévő kalcit Mg-tartalmának idő- (azaz mélység-) és térbeli (azaz Ny-K irányú) változását. Megállapításaik szerint kisvízi körülmények között a bepárlódó, nagyobb ionerôsségú vízból $\mathrm{Mg}$-ban dúsabb, míg magas vízállásnál, hígabb oldatból Mg-szegényebb kalcit válik ki. Ennek megfelelően az iszap $\mathrm{Mg} / \mathrm{Ca}$ arányából az éghajlat (nedves/száraz időszakok) fluktuációjára lehet következtetni. A környezeti változások felderítésében további érdekes eredményeket ígér a MAGYARI Enikő vezetésével jelenleg is folyó kutatás, melynek keretében 2017 januárjában a Balaton jegéról fúrták át a holocén iszapot (MAGYARI et al. 2019). Az 1970-es és 1990-es években végzett hasonló vizsgálatokhoz képest (MÜLLER \& WAGNER, 1978, CSERNY et al. 1991b) a múszeres analitikai lehetőségek óriási fejlődése minden korábbinál részletesebb elemzést tesz majd lehetővé.

A kicsapódó karbonát Mg-tartalmával kapcsolatban a fentieken túl feltétlen említendő a (proto)dolomit képződése. A Balatonról szóló számtalan tudományos publikáció közül mindeddig alighanem egyetlen cikk jelent meg a Nature-ben, és ez a protodolomitról szól (MüLLER 1970). Bár a protodolomit fogalma nem egészen tisztázott (GAINES 1977), amint ezt a Földtani Közlöny egyik ünnepi cikke is kifejti (HAAs \& HIPS 2020), itt olyan karbonátásványra használjuk, amelynek összetétele a dolomitét közelíti, de a Mg és Ca legfeljebb csak részlegesen rendeződik szerkezetében. MÜLLER \& WAGNER (1978) és késôbb CSERNy et al. (1991b) illetve TULLNER (2002) is ebben az értelemben használták a fogalmat. Az idézett szerzôk egyetértettek abban, hogy a protodolomit az iszapban a Mg-tartalmú kalcit átalakulásával képződik „,bepárlódó”, azaz kisvízi körülmények között, amikor az iszap pórusvizének különösen nagy a Mgkoncentrációja.

Saját vizsgálataink felvetették a lehetőségét, hogy közel dolomit összetételú karbonátásvány a vízből is kiválhat (TompA et al. 2014). Az iszapról, de különösen a lebegó anyagról készült röntgen-pordiffraktogramok ugyanis kétféle dolomit jelenlétére utaltak: egy sztöchiometrikus (valószínúleg allochton, triász eredetú) és egy Ca-gazdag változatra (amilyen például a 7. ábrán látható romboéderes dolomit). Mivel az utóbbi a nagy oldott $\mathrm{Mg} / \mathrm{Ca}$ aránnyal jellemezhető keleti medencéből vett iszap- és lebegőanyag-mintákban fordult elő (ToMPA et al. 2014, RosTÁsI et al. 2019, RosTÁsi et al. 2020), nagy a valószínúsége, hogy a Ca-gazdag dolomit képződése a pillanatnyi vízkémia függvénye, tehát közvetlenül a vízből válik ki.

Mivel a jelenleg képződő balatoni iszapban ez a nem sztöchiometrikus dolomit egészen kis mennyiségben fordul elő, érdemes a Balatonhoz sok tekintetben hasonló, de még Mg-dúsabb Fertő iszapját is megvizsgálnunk. A Fertőben azonosítottak egy dolomitösszetételú fázist, amelyről sokféle (kémiai, stabil- és radiogén izotópos) vizsgálat alapján megállapították, hogy nem az iszapban, hanem a vízoszlopban képződik (FussMANN et al. 2020). Saját TEM-méréseink szerint a Fertő iszapjában - a Balatonhoz hasonlóan - a 
karbonátásványok szmektitpelyheken képződnek. A kis szemcseméretú $(<2 \mu \mathrm{m})$ frakcióban a karbonátásványok összetételének eloszlása a kis $(2 \%) \mathrm{MgCO}_{3}$-ot tartalmazó kalcittól a dolomitig $\left(50 \% \mathrm{MgCO}_{3}\right)$ terjedő tartományban folyamatos. Sőt, jellemzően egy-egy szemcsén belül is előfordulnak kis Mg-tartalmú kalcitból és dolomitból álló zónák (PósFAI et al. 2019b). A Mg-tartalom szempontjából „tarka” képet mutató szemcsék képződésének értelmezése jelenleg is folyik; úgy véljük, hogy mind a kristálycsíra-képződés, mind a kristálynövekedés (sôt feltételezhetően visszaoldódás/növekedés) szerepet játszhatott a komplex összetétel kialakításában.

Mindeddig csak a (proto)dolomit összetételéről volt szó, de természetesen a kristályszerkezet vizsgálata ad választ arra a kérdésre is, hogy egy rendezetlen, nagy Mg-tartalmú kalcitról van-e szó, vagy dolomitról, amelyben a Mg és Ca rendeződik és a $c$ tengely mentén váltakozva tölti be a kationrétegeket. A szakirodalom azt a fázist tekinti dolomitnak, amelynek diffrakciós felvételein a ,rendezettségi reflexiók" - mint például az 105 és 10-1 Miller-indexúek - megjelennek (GREGG et al. 2015). A feljebb ismertetett Fertó tavi, dolomitos összetételú szemcsék jellemzően mutatnak ilyen reflexiókat az elektrondiffrakciós felvételeken, azonban ezeknek a (kalcitban is megjelenő) szubcella-reflexiókhoz viszonyított intenzitása meglehetősen változatos (11. ábra). Ez a megfigyelés előrevetíti, hogy a $\mathrm{Mg} / \mathrm{Ca}$ rendeződés nem tökéletes, és szemcsérôl szemcsére változhat (PósFAI et al. 2019b). Nagy felbontású, sötét látóterú STEM(pásztázó TEM-) felvételek még több információt hordoznak a szemcsén belüli rendeződésről (12. ábra). Ezeknek a felvételeknek a jellegzetessége, hogy a kontraszt az átlagrendszámmal négyzetesen arányos. Leegyszerúsítve: a világosabb pöttyök Ca-ban gazdagabb, a kevésbé világosak $\mathrm{Mg}$ gazdag kationoszlopokat reprezentálnak. A 12. ábra felvételén látható, hogy a szemcse egyes részein minden második pontsor intenzívebb - azaz ezekben a doménekben láthatóan van $\mathrm{Ca} / \mathrm{Mg}$ rendeződés -, míg máshol a pontsorok intenzitása homogén, azaz nincs rendeződés. A képintenzitás alapján számolható a kationoszlopok betöltöttsége. Ez alapján a rendezett területen sem kizárólag $\mathrm{Mg}$-mal, ill. Ca-mal
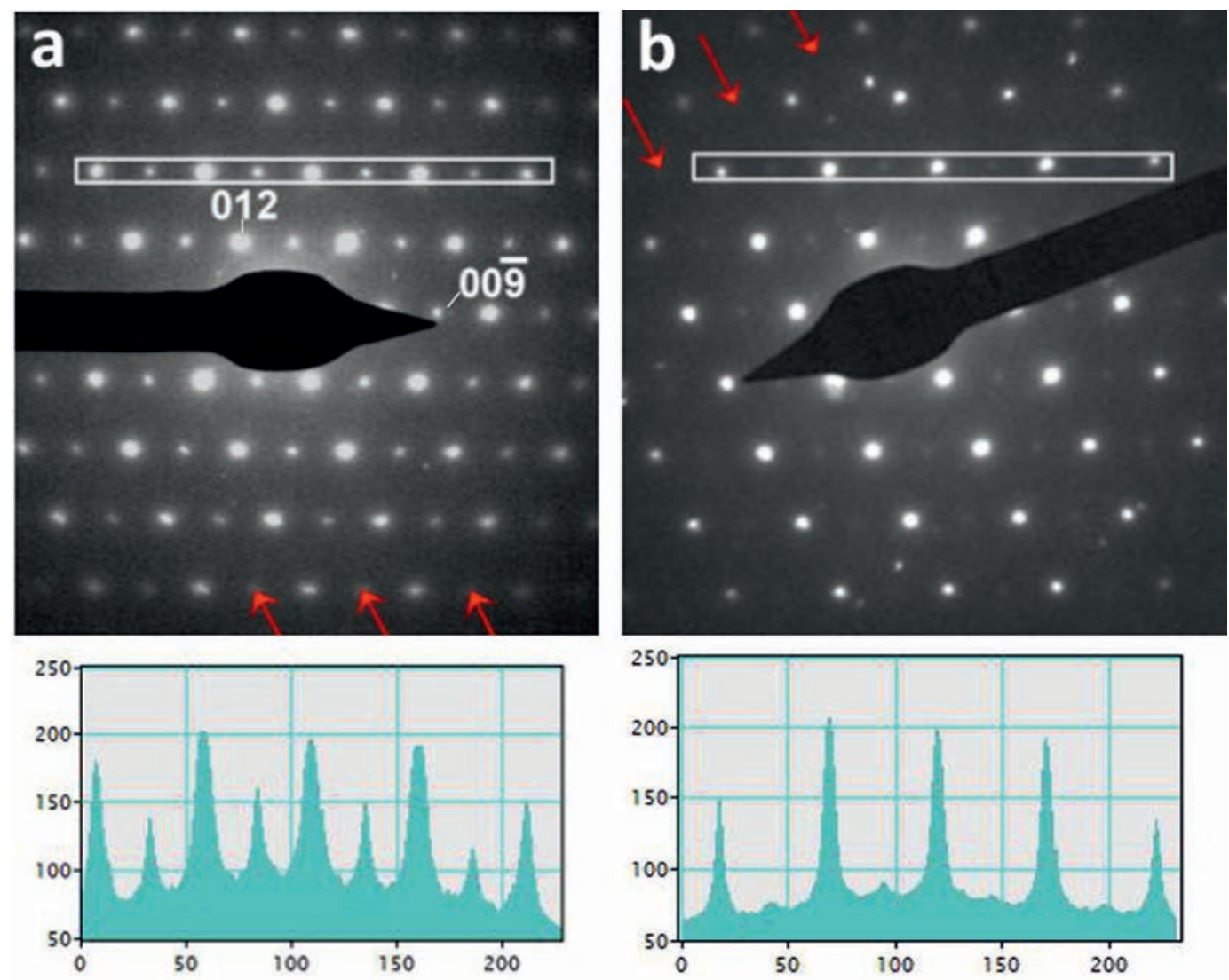

11. ábra. Fertő tavi, dolomithoz közeli összetételű karbonátszemcsékről, [100] vetületben készült elektrondiffrakciós felvételek, a fehér téglalappal jelölt területeken belüli reflexiók intenzitásprofiljaival együtt. Mindkét felvételen a piros nyilakkal jelölt reflexiósorok megjelenése a $\mathrm{Ca}$ és $\mathrm{Mg}$ rendeződésére, dolomitszerkezetre utal. Az (a) ábrán a rendeződést jelző reflexiók jóval nagyobb intenzitásúak, mint a (b) esetében. Az (a) ábrán a könnyebb térbeli tájékozódás érdekében két reflexió Miller-indexét feltüntettük.

Figure 11. Electron diffraction patterns from two carbonate grains (obtained along [100]) with compositions close to that of dolomite, collected from the sediments of Lake Fertö, another shallow, calcareous lake with Mg-rich water. The intensity distributions of the boxed rows of relections are also shown. The red arrows point to rows of reflections the presence of which suggests a dolomite-like ordering of Ca and Mg in the structures of both grains; however, in pattern (a) the intensities of the ordering reflections are much stronger than in (b) For easier orientation in space, the Miller indices of two reflections are shown in panel (a) 

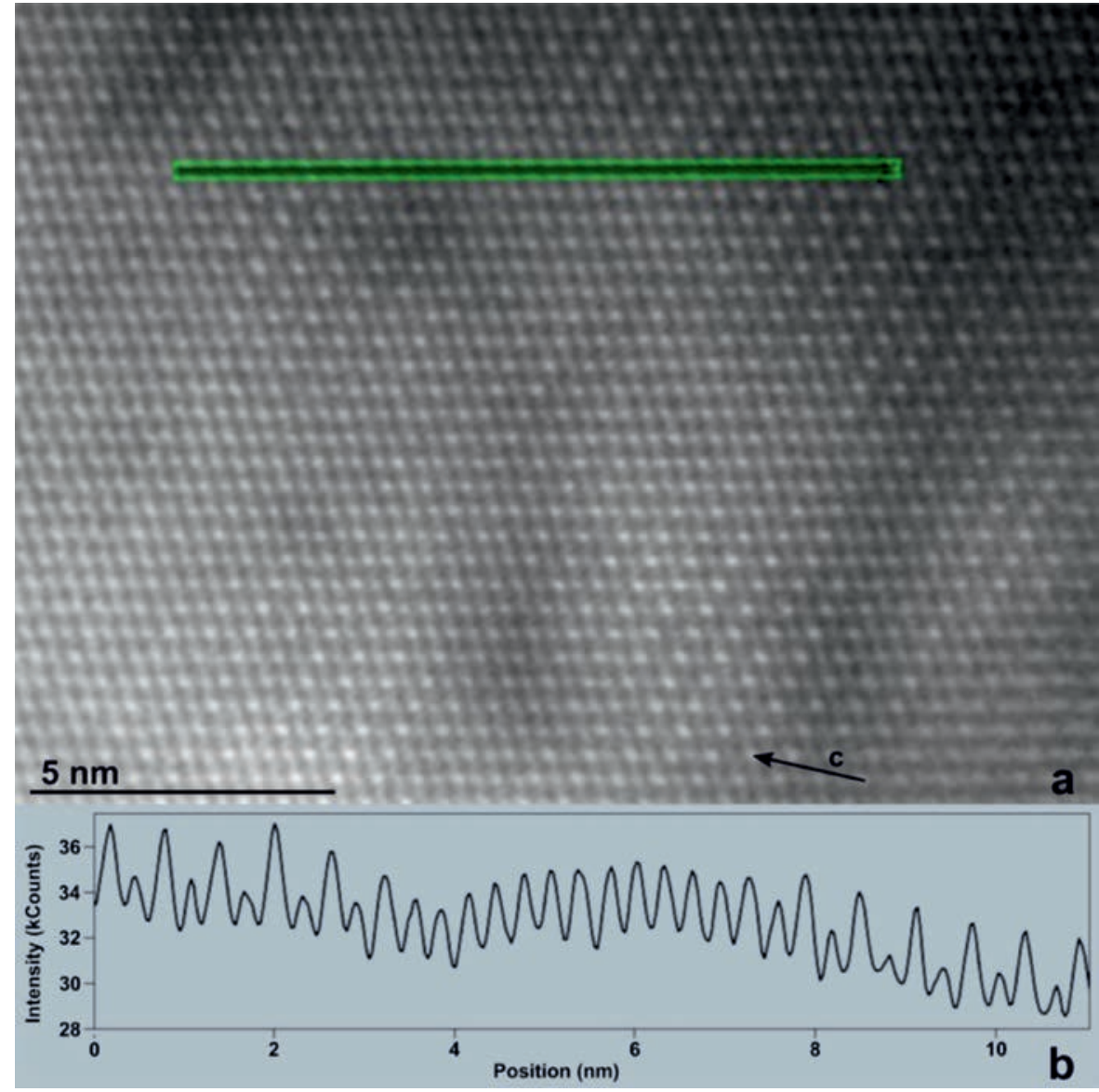

12. ábra. Nagy felbontású, sötét látóterủ STEM-felvétel egy Fertő tavi, dolomit összetételủ karbonátszemcséről, [100] vetületben, a zöld téglalappal jelölt területen belüli intenzitásprofillal együtt. Míg a profil két szélén kis és nagy képintenzitást eredményező kationpozíciók váltakoznak (a $\mathrm{Mg} / \mathrm{Ca}$ rendeződés miatt), a profil közepén közel azonos intenzitást eredményező kationpozíciók vannak. (PEKKER Péter felvétele)

Figure 12. High-resolution, high-angle annular dark-field STEM image of a carbonate grain with dolomitic composition from Lake Fertö sediments, viewed with the electron beam parallel to [100]. The intensity profile of the boxed area is shown below the image. Whereas cation positions with low and high contrast alternate in the left and right sides of the intensity profile, positions with approximately equal contrast occur in the middle. (Image courtesy of Péter PEKKER.)

betöltött pozíciók vannak, hanem szemcsétől függően pl. $70 \% \mathrm{Mg}+30 \% \mathrm{Ca}$-ot és $30 \% \mathrm{Mg}+70 \% \mathrm{Ca}$-ot tartalmazó kationoszlopok váltakoznak. A feljebb már sok helyen említettekhez hasonlóan a $\mathrm{Mg} / \mathrm{Ca}$ rendeződés vizsgálata is folyamatban van, eredményeinket még csak előadáskivonatokban jelentettük meg. Annyi azonban már kijelenthető, hogy a 11. és 12. ábrához hasonlókat nemcsak a Fertő, hanem a Balaton iszapjában lévő karbonátok esetében is látunk. A néhány nm-es méretú, (részlegesen) rendezett, illetve rendezetlen domének váltakozása magyarázza a protodolomit diffrakciós tulajdonságait, és új megvilágításba helyezheti a tavi dolomitképződés folyamatát.

A Balaton iszapjának uralkodó ásványa a Mg-tartalmú kalcit, amint ezt sok korábbi kutatás is megállapította. Ez a tény azonban egyáltalán nem triviális, hiszen - bár a tiszta $\mathrm{CaCO}_{3}$ polimorfok között a kalcit a stabil fázis (5. ábra) - a Balaton vizének jelentős Mg-tartalma miatt termodinamikailag az év nagyobb részében a dolomit lenne a stabil karbonátásvány. Mint ismert, a dolomit kiválása kinetikailag gátolt, viszont ebben az esetben is - ugyancsak a Mg-tartalom miatt az aragonit kiválása sem lenne meglepó (SuN et al. 2015). BIDLó (1960) le is írt a Balaton vizéből közvetlen aragonitkiválást, mégpedig vízinövények levelein, és mi is tapasztaltuk aragonittúk keletkezését Balaton-vízben tenyésztett algákon. A kristálycsíra-képződésről szóló részben említettem, hogy a „nem klasszikus” csíraképződés során amorf ionklaszterek aggregálódnak. Ezek kristályosodására jellemző az Ostwaldféle lépcsôszabály: az oldatból előbb a legkevésbé stabil fázis válik ki, amely sorozatos fázisátalakulással végül a termodinamikailag stabil szerkezetté kristályosodik. $\mathrm{A} \mathrm{CaCO}_{3}$ esetében ez azt jelenti, hogy először amorf kalcium-karbonát válik ki, amely több lépésben, vateriten és aragoniton át végül $\mathrm{Mg}$ tartalmú kalcittá alakul. Valószínúleg ez a folyamat a Balatonban is lejátszódik, azonban olyan gyors lehet, hogy az eddigi mintavételek már csak a végtermék kalcitot tudták kimutatni. Laboratóriumi kísérleteink alátámasztják a fenti állítást, és arra utalnak, hogy a szmektit agyagásványnak fontos szerep jut a folyamat gyorsításában: Mg-mentes oldatból szmektit 
nélkül vaterit, szmektit jelenlétében viszont közvetlenül kalcit kiválását figyeltük meg (MoLNÁR et al. 2020a). Ellenben a Balaton vizéhez hasonló, Mg-dús oldatból laboratóriumi körülmények között előbb aragonit vált ki, amely szmektit jelenlétében több hónapos érlelés után alakult át részben $\mathrm{Mg}$ tartalmú kalcit és rendezetlen dolomit aggregátumává (MoLNÁR et al. 2020a). Ezek a kísérletek jelenleg is zajlanak, és remélhetőleg mind a balatoni karbonátképződésre, mind a protodolomit képződésére vonatkozóan új ismereteket eredményeznek.

A Balatonban többnyire BIM-folyamatok révén képződő ásványok közül a karbonátásványokon kívül említésre méltók a vas-oxidok és -szulfidok. Ezekről jelenleg nagyon keveset tudunk, pedig a vas-oxidokról ismert, hogy fontos szerepet játszanak a foszfor körforgalmában (SMOLDERS et al. 2017), a vas-szulfidok között pedig az üledék mágneses tulajdonságait meghatározó fázisok is lehetnek (MÁRTON et al. 2007). A vas-oxidok feltehetően oxidált fázisokban, goethit és ferrihidrit formájában vannak jelen az iszapban, de ennél többet pillanatnyilag nem tudunk róluk. A framboidális pirit az üledék reduktív zónájában képződik, jelenlétét CSERNy et al. (1991b) és Hámor (1994) pásztázó elektronmikroszkópos felvételekkel igazolta. Az általunk elemzett röntgendiffrakciós felvételeken a pirit szinte minden mintában megjelent, de kis $(0,5-1,5 \%)$ mennyiségben. A balatoni iszap mágneses tulajdonságait MÁRTON et al. (2007) vizsgálta. A szárazra kerülő iszap elveszíti mágnességét, ami vas-szulfidokra (pl. a greigitre) lehet jellemző, azonban ezt az ásványt eddig nem sikerült azonosítani (MÁRTON, szóbeli közlés). A foszfort a képletükben is tartalmazó ásványok közül az apatitot sikerült egyszer, a nehézásvány-frakcióban kimutatni (DoBOlYi \& BIDLó 1980), de nem világos, hogy nem autochton eredetű szemcsérôl van-e szó.

\section{Biológiailag szabályozott ásványképződés (BCM) a Balatonban}

Kétségtelen, hogy a Balaton legismertebb BCM ásványa a kagylók (és kisebb részben csigák) héját alkotó aragonit. A puhatestú-faunával az elmúlt 90 évben behatóan foglalkoztak a Balatoni Limnológiai Intézet munkatársai, de természetesen nem az ásványtani jellegzetességekre, hanem a biológiai és ökológiai vonatkozásokra koncentrálva. Az elmúlt évtizedek fejleményei közül számunkra a legfontosabb két Dreissena faj inváziója: a Dreissena polymorpha még az 1930-as években, míg a Dreissena bougensis 15 éve jelent meg a Balatonban (BALOGH et al. 2018). Az előbbi elsősorban a parti kőszórásokat, míg az utóbbi már a nyíltvízi iszap felszínét is kolonizálta. Jelenleg a Dreissena kagylók akkora biomasszával vannak jelen a vízben, hogy szưrő tevékenységük révén még a víz átlátszóságának növekedéséhez is jelentősen hozzájárulnak (PósfAi \& G.-TóTH 2020).

Felvetődött, hogy a Dreissena bougensis megjelenésével és rohamos elterjedésével felhalmozódó aragonithéjak gyorsítják a Balaton feliszapolódásának folyamatát. BÁLDI et al. (2019) különböző szcenáriókat modellezett, amelyek többsége igen jelentős héjfelhalmozódással járt. Feltúnô azonban, hogy az iszap felső $10 \mathrm{~cm}$-érôl kapott röntgendiffraktogramjaink egyáltalán nem, vagy csak elenyészó mennyiségú aragonitot mutattak ki. Bár egyes helyeken látványos zátonyok alakulnak ki a kagylóhéjakból (13. ábra), időnként ezek eltúnnek. Az eltûnés oka természetesen a vízmozgás is lehet, de felmerült a gyanú, hogy a kagylóhéjak vissza is oldódhatnak. Az utóbbi néhány évben magasan tartott vízszint és csapadékosabb időjárás „hígabb” vizet eredményezett, amely - különösen télen és a víznél savasabb üledékben (lásd 5. ábra c) - az aragonitra nézve alultelített

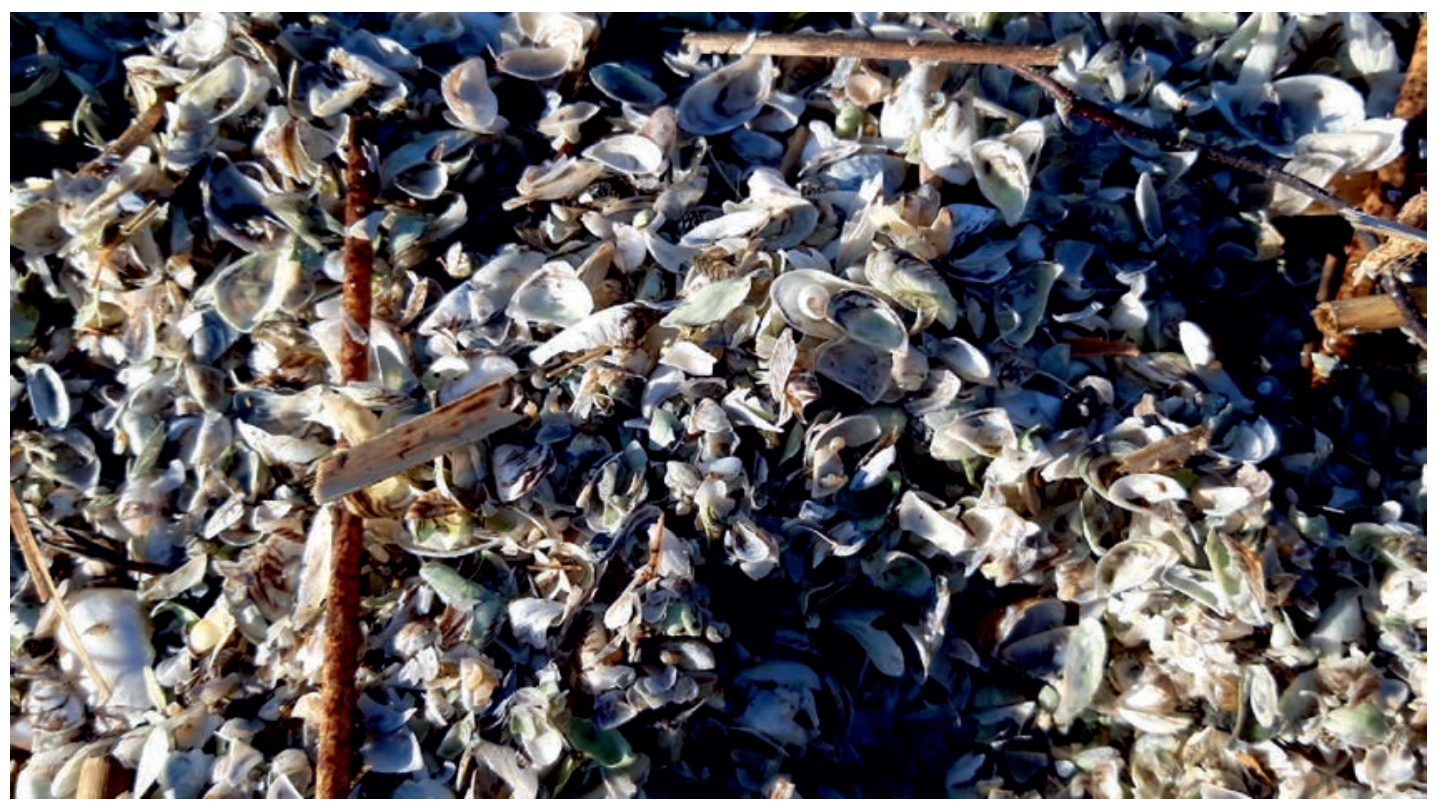

13. ábra. Dreissena-héjak part menti felhalmozódása a tihanyi révnél, 2020. februárjában

Figure 13. An accumulation of Dreissena shells along the shore at the ferry port of Tihany, in February of 2020 
viszonyokat hozott létre. Egy egyetemi szakdolgozat keretében alaposabban is vizsgáltuk ezt a kérdést, és a Balatonba kihelyezett kagylóhéjakon néhány hónap után ugyanolyan oldási nyomokat (és tömegcsökkenést) figyeltünk meg, mint a laboratóriumban, szénsavval oldott héjakon (NYOKABI 2020). Durva becslésünk szerint a kagylóhéjak felezési ideje kb. 4 év, ami azt jelenti, hogy bár egy részük valószínúleg eltemetődhet és megmaradhat az üledékben - hiszen kagylóhéjakat a korábbi fúrásokban is szép számmal találtak (CSERNY 2002) -, a héjak okozta feliszapolódással aligha kell számolni.

Ásványtani érdekesség, hogy a Dreissena-héjak aragonitja kivétel nélkül sûrûn ikresedett (14. ábra). Mivel az aragonitra - nemcsak a biogén eredetûre - általában is jellemző az ikresedés (GAVRYUSHKIN et al. 2019), nem biztos, hogy a több irányú és sûrú ikerhatárok csak a kagylóhéjak különlegességei. Van azonban olyan tanulmány, amely szerint az ikresedés növeli a héj mechanikai stabilitását, mert az ikerhatárok megakadályozzák a repedések terjedését (JI et al. 2020).

A kagylóhéjak nagyon hasznosak lehetnek a környezeti változások kutatásában. SCHÖLL-BARNA (2011) a balatoni Unio pictorum kagyló növekedési sávjaiból vett minták oxigén stabilizotóp-elemzésével kalibrálta az elmúlt két évtized időjárásának hatásait, és ennek segítségével, régészeti feltárásokból származó kagylók vizsgálatával ki tudta mutatni a késő rézkorszak éghajlati változásait (ScHÖLLBARNA et al. 2012).

A Balatonban nemcsak egysejtúek és puhatestúek, hanem gerincesek is választanak ki BCM karbonátásványokat. A halak otolitjai (hallócsontjai) fôleg aragonitból állnak, de kisebb részben a ritkább $\mathrm{CaCO}_{3}$-polimorf, a vaterit is elófor-

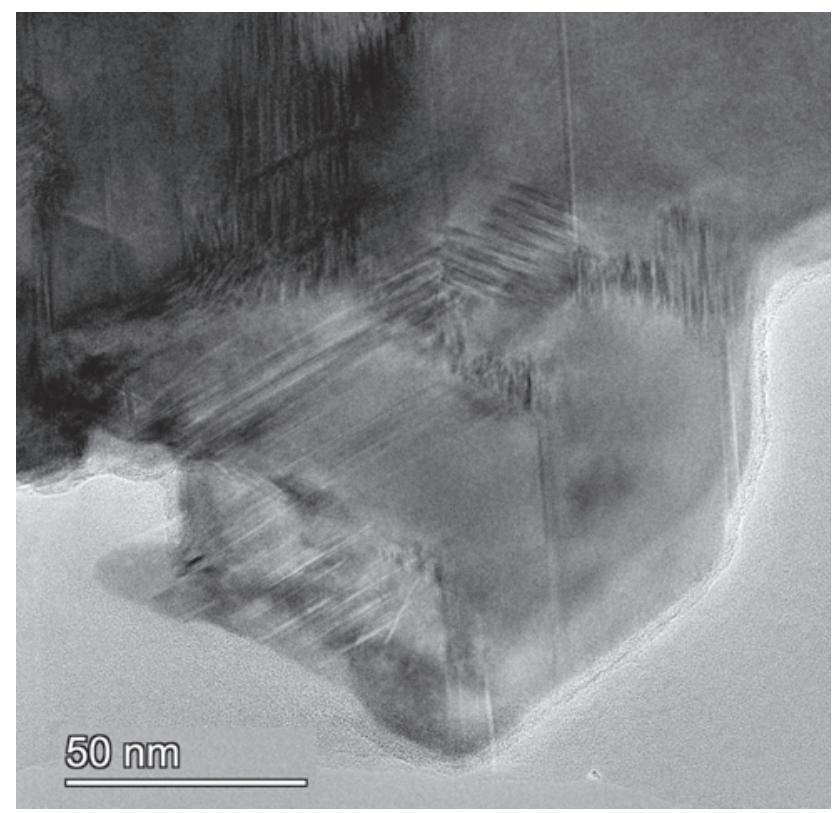

14. ábra. TEM-felvétel egy Dreissena-héjtöredékről; a vonal menti kontrasztok az aragonit ikerhatáraira utalnak

Figure 14. TEM image of a fragment of a Dreissena shell; the linear contrast features represent twin boundaries in the aragonite structure dul bennük (CAMPANA 1999). Az otolitok potenciális környezetjelzóként használhatók, hiszen folyamatosan nőnek, és így a fák évgyưrűiihez hasonlóan információt hordoznak a környezeti változásokról. Elvileg a növekedési sávok nyomelem- és stabilizotóp-vizsgálata utalhat a hal élete során bejárt környezet kémiai és fizikai jellemzőire. A valóság azonban ennél bonyolultabb: balatoni halak otolitjain végzett előzetes vizsgálataink szerint egyáltalán nem egyértelmú, melyik irányban nô a hallócsont. Világos és sötét sávok ugyan elkülöníthetôk, ezek azonban időnként elvégződnek vagy elágaznak, tehát mégsem adnak a fa évgyưrúihez hasonló, egyértelmú információt. Valószínúleg különbözó időszakokban más-más irányok mentén nő a hallócsont. Szerkezetileg viszont sok érdekesség is megfigyelhetô az aragonitban (MoLNÁR et al. 2020b), ám ezekről még korai lenne a jelen dolgozatban beszámolni. A balatoni halak közül tudtommal egy angolna hallócsontjáról készült eddig tudományos közlemény (KERN et al. 2017), amelyben Ramanvizsgálatokkal vateritszektorok jelenlétét mutatták ki a túlnyomóan aragonitból álló csontban.

A kagylóhéjak mellett a másik, nagy mennyiségben lévő BCM-ásvány az amorf kova, amely elsősorban a kovaalgák vázaként vagy a vázak töredékeiként egyik fó alkotója az iszapnak. Az iszap elektronmikroszkópos felvételein szinte elkerülhetetlenül szemünkbe tûnik egy-egy díszes héj vagy akár egy egész kovaalga-kolónia (15. ábra). A kovaalgák a limnológusok egyik kedvelt taxonómiai célcsoportja, hiszen a különböző fajok jelenléte olykor érzékenyen tükrözi a környezetük változásait. Különböző csoportjaikon (planktoni és bevonatalkotó) belül is további funkcionális csoportok különíthetôk el (TAPOLCZAI et al. 2016), amelyek másmás környezeti tényező vizsgálatára adnak lehetôséget. Geológus szemmel azt gondolhatnánk, hogy az elpusztult kovaalgák vázai „örökre” az iszap alkotóivá válnak. A balatoni iszapfúrások kovaalgaanyagát alaposan feldolgozták (CSERNY et al. 1991b, BuCZKó et al. 2005), amiből látható,

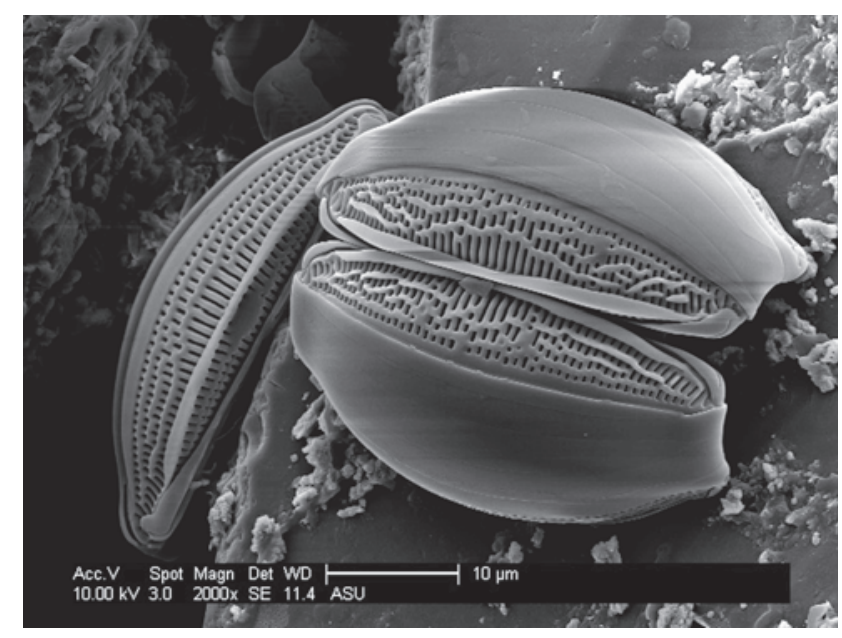

15. ábra. Kovaalgák kvarcon, mellettük a tóból kivált Mg-tartalmú kalcit kisebb szemcséi, egy Sajkodon kihelyezett üledékcsapdából (SEM-felvétel)

Figure 15. SEM image of diatoms on a grain of quartz, with smaller grains of $M g$ bearing calcite that precipitated from the lake, collected in a sediment trap at Sajkod 
hogy valóban vannak teljesen érintetlennek túnő kovavázak az iszap mélyebb rétegeiben is. Azonban a kagylóhéjakhoz hasonlóan a kovaalgák vázai sem feltétlen élik túl a tavakban gyakori és sokszor biológiailag indukált vízkémiai változásokat, elsôsorban a lúgosabb pH-t. Általában 50 napra becsülik a tavi kovaalgavázak felezési idejét, de ennél még jóval rövidebb (8 napos) felezési idôt is megfigyeltek (PADISÁK et al. 2003). A szilícium tehát állandó körforgásban van az élő és az elpusztult szervezetek vázai között, ami felveti akár annak a lehetőségét is, hogy a feljebb sokszor említett, nm-es méretû szmektitpelyhek esetleg nem is allochton eredetúek, hanem a vízben képződnek.

Végül a BCM-ásványok egyik egzotikus képviselője a magnetit, amely a mágneses baktériumok sejtjeiben képződik (16. ábra). A Balaton esetében tudtommal csak saját vizsgálatainkra hivatkozhatunk (PÓSFAI \& ARATó 2000, NYIRŐ-KÓSA \& PÓSFAI 2007). A magnetitet kiválasztó mágneses baktériumok mikroaerofilek, azaz életterük az oxikus-anoxikus átmeneti zóna (BAZYLINSKI \& FRANKEL 2004), amely a Balatonban általában az üledék legfelsố né- hány mm-ében húzódik. A sejten belül, genetikai szabályozás által meghatározott módon, egy „magnetoszómamembrán" határolta térben (16. ábra c) képződő mágneses nanokristályok láncai a Föld mágneses erôvonalai mentén pasz-szívan orientálják a sejtet, amely ezáltal kénytelen levagy felfelé úszni. Ez a vonal menti, liftező mozgás segíti a baktériumot abban, hogy a függóleges kémiai (elsôsorban oxigén-) gradiensek mentén hamarabb megtalálja a számára kedvező koncentrációt. Többféle helyről és különböző időszakokban vett iszapmintákban mágneses dúsítással vizsgáltuk a különböző sejtmorfológiai típusok előfordulását, majd az egyes sejttípusok magnetit-magnetoszómáinak jellegzetességeit. Sokféle mágneses sejttípus (coccus, spirillum, vibrio) előfordul a Balatonban, amelyekben változatos magnetitláncok (egyes, kettős, rendezetlen) és nanokristálymorfológiák (kubooktaéderes, hasáb és nyílhegy alakúak) figyelhetôk meg (NYIRŐ-KóSA \& PÓSFAI 2007). Különösebb rendszert azonban nem sikerült felfedeznünk az egyes típusok eloszlásában, és a képződő magnetit mennyiségét sem tudtuk becsülni. Érdekes azonban, hogy sokféle coccus
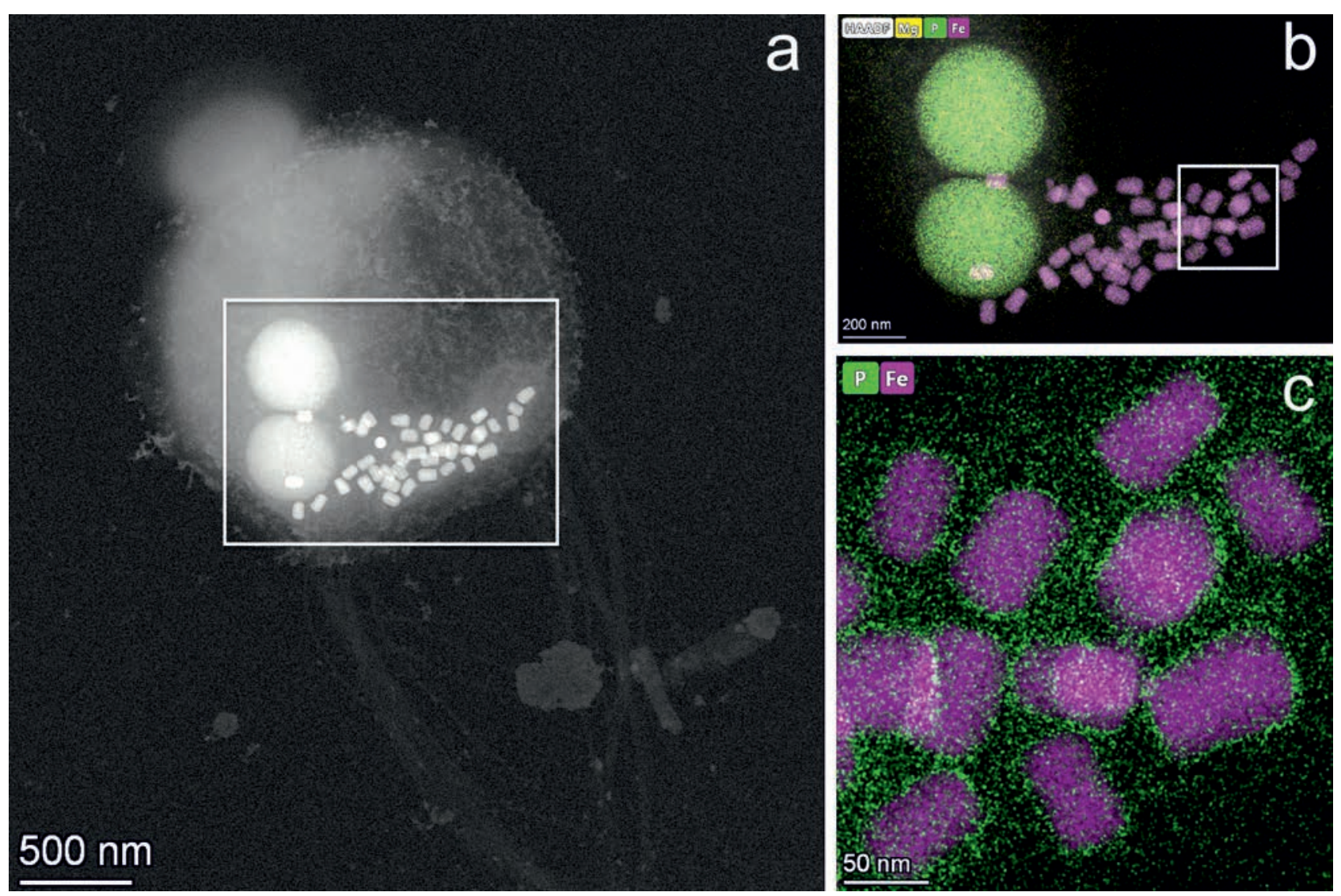

16. ábra. Balatonudvari strandjának iszapjából izolált, coccus morfológiájú mágneses baktérium sejt. (a) Sötét látóterủ STEM-felvétel a teljes sejtről, rajta a sejt mozgását biztosító két köteg flagellum, a sejten belül két kerek zárvány és hasáb alakú magnetit-magnetoszómák rendezetlen lánca is látható. (b) Sötét látóterű STEM-felvétel és EDS-elemtérképek ( $\mathrm{Mg}$, P és Fe) kompozíciója az (a) táblán bekeretezett részről; a két zárvány foszfor-és magnéziumtartalmú, és csak a magnetitmagnetoszómák tartalmaznak vasat. (c) A vas és a foszfor eloszlását mutató elemtérkép a (b) táblán bekeretezett részről. A magnetitrészecskéket keretező foszfordúsulás a magnetoszóma-membrán (foszfolipid kettősréteg) jelenlétének köszönhetó

Figure 16. A cell of a magnetotactic bacterium with coccus morphology, isolated from the sediment of the beach in Balatonudvari. (a) Dark-field STEM image of the whole cell, showing two bundles of flagella that are used by the cell for motion, two round-shaped inclusions and a band of prismatic-shaped magnetite magnetosomes. (b) A composite of a dark-field STEM image and EDS elemental maps (for Mg, Fe and P), obtained from the boxed area in ( $(\mathrm{)})$; the two large inclusions are P-and Mg-rich, and Fe is present in the magnetite magnetosomes only. (c) EDS elemental map of Fe and P from the boxed area in (b); the Penrichment around the magnetite particles is due to the presence of a magnetosome membrane (a phospholipid bilayer) 
morfológiájú baktériumra jellemző a nagymértékú foszforfelhalmozás, a sejtmérethez képest két óriási polifoszfát zárványt tartalmaznak (16b. ábra). Az iszap mélyebb rétegeiben is kerestük a „magnetofosszíliákat”, azaz az elpusztult mágneses baktériumok sejtjeiből származó magnetitkristályokat, ilyeneket azonban nem találtunk. Feltehetően a reduktív közegben a magnetit-nanokristályok visszaoldódnak, anyaguk hozzájárulhat a feljebb említett framboidális pirit képződéséhez.

\section{Zárógondolatok}

A Balaton kutatása kezdettől szolgálta mind alapvető általános (alapkutatási) tudományos kérdések megválaszolását, mind konkrét, alkalmazott feladatok megoldását. Ma sincs másképp, a sokszor öncélúnak tûnő, részletekbe menő vizsgálatok később - olykor előre nem várt módon - gyakorlati szempontból is hasznosulhatnak. Egy friss példa: a szmektit karbonátkicsapódást elősegítő szerepéről szóló munkáinkra (is) hivatkozva oldottak meg egy geotechnikai problémát, a durva homok karbonátos cementálását bentonit hozzáadásával (MA et al. 2020). A Balaton ökológiai rendszerének - beleértve az iszap ásványait is - minél alaposabb, tudományos igényú ismerete szükséges ahhoz, hogy a tó számunkra annyira fontos ,,jó” állapotát, azaz fürdésre, sportolásra alkalmas vízminőségét hosszú távon fenntartani lehessen.

Visszatérve a Bevezetésben említett, a Balaton vízmi- nősége szempontjából jelenleg legfontosabb problémára: a 2019-es algavirágzás okait még nem ismerjük. A kulcsfontosságúnak tartott tápanyag, a foszfor az üledékben raktározódik, de a kémiai formájáról csak múveletileg definiált, sorozatos oldási módszerek adtak eddig információt. Attól függően, hogy mely oldószerrel lehet kivonni az üledékből, a foszfort különböző kategóriákra osztják: „felvehető”, „,vashoz kötött”, „karbonáthoz kötött”, ,,szerves anyaghoz kötött" (IstváNOVICS et al. 1989). A Balaton üledékében a legnagyobb frakció a karbonáthoz kötött foszfor, de nem elhanyagolható - különösen a Keszthelyi-öbölben - a vashoz kötött foszfor sem. Fontos lenne azonban közvetlenebb módszerek alkalmazásával megismernünk a foszfor megkötődésének módját, mert csak akkor tudjuk megérteni a felszabadulásának feltételeit is. A probléma a foszfor viszonylag kis koncentrációja, diszperz eloszlása és legfóképpen a rendkívül bonyolult körforgalma a bióta egyes elemein belül (PADISÁK \& REYNOLDS 1998, IsTVÁNOVICS 2008). Ezért elektronmikroszkópos módszerekkel próbáljuk megtalálni az üledékben a foszfort, elsősorban a karbonáthoz és a vashoz kötött részét. A kezdeti próbálkozások ígéretesek (17. ábra), de ennek a kutatásnak még csak az elején járunk. Remélhetőleg a karbonátképződésről eddig felhalmozott információ segítséget nyújt majd a foszfor speciációjának, valamint az üledék és algák közötti forgalmának megértéséhez is.

A balatoni iszap rendkívül dinamikus rendszer, nemcsak fizikai, hanem kémiai értelemben is. Mint láttuk, a kagylók aragonithéjának és valószínúleg a kovaalgák szilikavázának
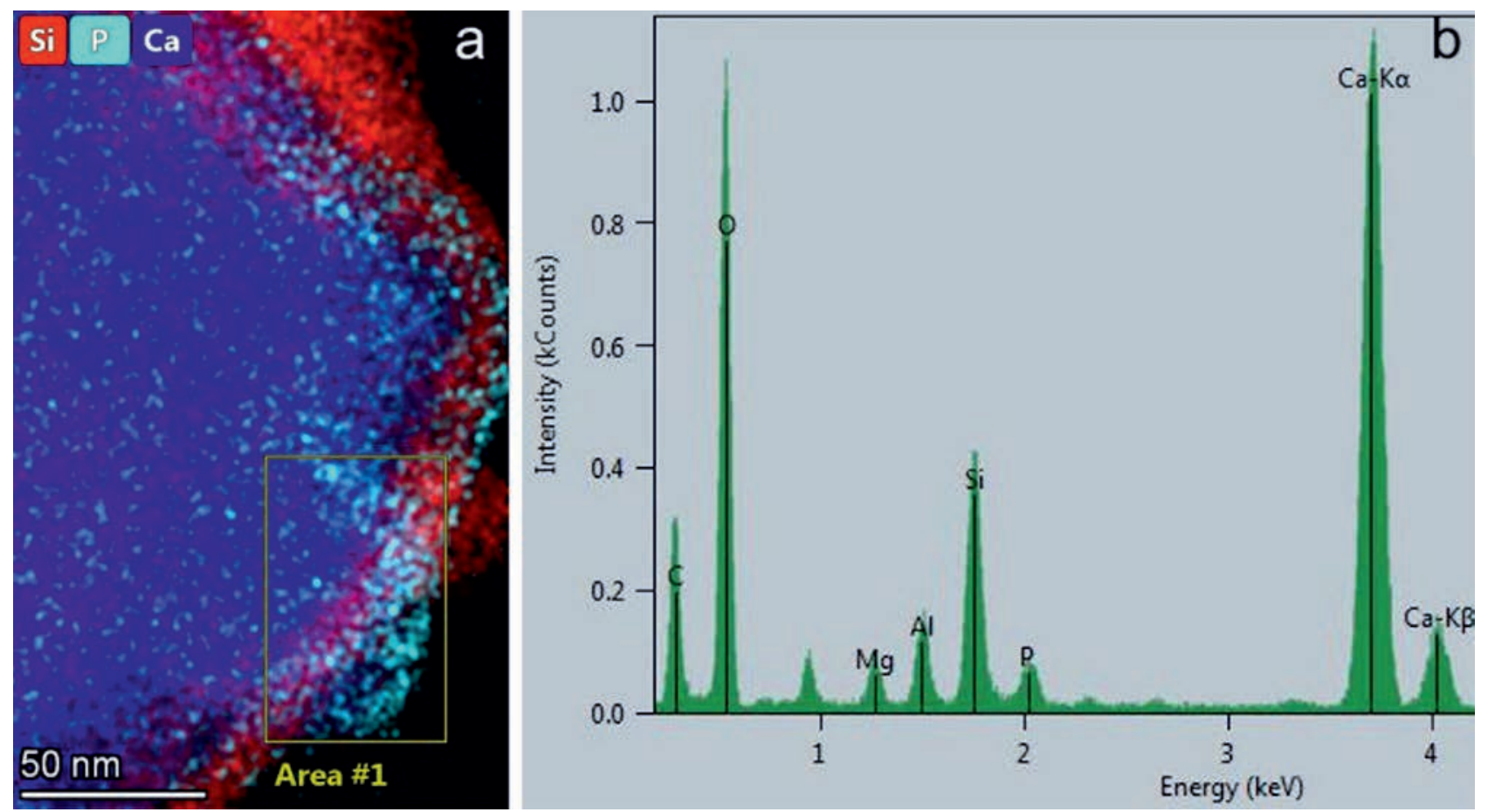

17. ábra. (a) STEM EDS-elemtérkép egy kalcitszemcséről (Ca: sötétkék), amelyet szmektitréteg burkol (Si: piros), a kalcit és az agyag határán foszfordúsulással (világoskék). (b) Az (a) táblán jelölt terület átlagos összetételét mutató EDS-spektrum; a foszfor koncentrációja mindössze 1.8 atom\%

Figure 17. (a) STEM EDS elemental map obtained from a calcite grain (Ca: dark blue), covered by a smectite flake (Si: red), with a minor P enrichment (in light blue) at the boundary between calcite and smectite. (b) EDS spectrum showing the composition of the boxed area in (a); the concentration of P is only 1.8 atom\% 
anyaga is körforgásban van a tavon belül. Az 5c. ábra szerint azonban évszaktól és időjárástól függóen rendszeresen előfordulnak olyan kémiai körülmények, amelyek mellett nemcsak az aragonit, hanem a kalcit, sôt akár a dolomit is visszaoldódhat. Ekkor a kalcithoz kötött foszfor, magnézium vagy egyéb elemek ismét mobilizálódhatnak. A viszszaoldódás/kicsapódás ciklusai olykor egy új egyensúlyi állapot kialakulását, és különösen az ásványok felületén új fázisok megjelenését eredményezik (RUIZ-AGUDO et al. 2014). A Balatonban ezek a folyamatok biztosan szerepet játszanak a karbonátok Mg-tartalmának megfigyelt változékonyságában és esetleg a protodolomit képződésében. A jövő kutatási feladata, hogy pontosabban felderítsük az iszapásványok felületén lejátszódó jelenségeket.

A Balaton kutatása alighanem addiktív: aki egyszer „,belekóstolt" a Balatonba, nehezen hagyja abba a vizsgálatát. Amíg az egyik kérdésre úgy-ahogy kielégítő választ kapunk, számtalan újabb megoldandó problémát találunk. Ez persze nagyjából minden tudományos kutatásra igaz, de a Balaton mégis különleges: épp megfelelô méretû ahhoz, hogy remélhessük, hogy egyszer tökéletesen megértjük a benne zajló folyamatokat, ugyanakkor kellően bonyolult rendszer ahhoz, hogy aztán belássuk, ez mégsem fog sikerülni. A balatoni iszapról legalább száz éve halmozódik a tu- dás, amelynek gyarapítása nemcsak élményekben gazdag tudományos munka, hanem kötelességünk is.

\section{Köszönetnyilvánítás}

A jelen dolgozatban említett tudományos eredményekhez sok munkatársam kutatómunkája járult hozzá. Másoktól konzultációk, irodalmi útbaigazítás formájában kaptam segítséget. Hálásan köszönöm MoLNÁR Zsombor, NYIRŐKósA Ilona, Rostási Ágnes, BERECZK-ToMPA Éva, FodOR Melinda, PeKKer Péter, Dódony István, RÁCZ Kornél, Winfred NyOKABI, Ható Zoltán, KRISTÓF Tamás, CsERnY Tibor, HaAs János, BALOGH Csilla, Patrick MeIster, Silvia Frisia, ToPA Boglárka, WeIszBuRg Tamás, IsTVÁnovics Vera, PADisÁK Judit, MagYari Enikő, PÁlfi Ivett, Kovács András, CORA Ildikó és Maja KoBlar segítségét. Köszönöm a kézirat átnézését és bírálatát, CSERNY Tibor, HAAS János, IsTVÁNOVICS Vera, PAPP Gábor és SzTANÓ Orsolya hasznos megjegyzéseit. A kutatást az OTKA K116732 és az NKFIH GINOP-2.3.2-15-2016-00017 és GINOP-2.3.3-152016-0009 számú projektjei támogatták. Az elektronmikroszkópos vizsgálatokhoz a Pannon Egyetem, Nanolab múszereit használtuk.

\section{Irodalom - References}

BABINSZKi E. \& HoRvÁtH F. (szerk.) 2020: A Balaton kutatása Lóczy Lajos nyomdokán. - Magyarhoni Földtani Társulat, Budapest, 339 p.

Báldi, K., Balogh, C., Sztanó, O., Buczkó, K., B. Muskó, I., G.-Tóth, L. \& Serfőző, Z. J. 2019: Sediment contributing invasive dreissenid species in a calcareous shallow lake - Possible implications for shortening life span of lakes by filling. - ELEMENTA Science of the Anthropocene 7/1, 42 p. https://doi.org/10.1525/elementa.380

Balogh, C., Vlácilová, A., G.-Tóth, L. \& SERFŐZŐ, Z. 2018: Dreissenid colonization during the initial invasion of the quagga mussel in the largest Central European shallow lake, Lake Balaton, Hungary. - Journal of Great Lakes Research 44/1, 114-125. https://doi.org/10.1016/j.jglr.2017.11.007

BAZYLINSKI, D. A. \& Frankel, R. B. 2004: Magnetosome formation in prokaryotes. - Nature Reviews Microbiology 2/3, 217-230. https://doi.org/10.1038/nrmicro842

BIDLó G. 1960: Balatoni aragonit-kiválás. - Földtani Közlöny 90, 224-225.

BuCZKó, K., VÖRÖs, L. \& CSERnY, T. 2005: The Diatom flora and vegetation of Lake Balaton from sediment cores according to Marta Hajós's legacy. - Acta Botanica Hungarica 47/1-2, 75-115. https://doi.org/10.1556/abot.47.2005.1-2.10

Budai T. \& Csillag G. 1998: A Balaton-felvidék középső részének földtana. - A Bakony természettudományi kutatásának eredményei 22, $118 \mathrm{p}$

CAMPAnA, S. E. 1999: Chemistry and composition of fish otoliths: pathways, mechanisms and applications. - Marine Ecology Progress Series 188, 263-297. https://doi.org/10.3354/meps188263

CSERNY, T. 2002: A balatoni negyedidőszaki üledékek kutatási eredményei. - Földtani Közlöny 132, 193-213.

CSERNY T. \& CORRADA R. 1990: A Balaton aljzatának szedimentológiai térképe. - A Magyar Állami Földtani Intézet Évi Jelentése az 1988. évról, 169-176.

CSERnY, T., NAGY-Bodor, E. \& HAJós, M. 1991a: Contributions to the sedimentology and evolution history of Lake Balaton. - In: PÉCSI, M. \& SCHweITZER, F. (szerk.): Quaternary Environment in Hungary. Studies in Geography in Hungary. Akadémiai Kiadó, Budapest, 75-84.

CSerny T., Földvári M., Ikrényi K., Nagy-Bodor E., Hajós M., Szuromi-Korecz A. \& Wojnárovits L. 1991b: A Balaton aljzatába mélyített Tó-24. sz. fúrás földtani vizsgálatának eredményei. - A Magyar Állami Földtani Intézet Évi Jelentése az, 1989. évról, 177-239.

CSERny, T., Hertelendi, E. \& TARJÁN, S. 1995: Results of isotope-geochemical studies in the sedimentological and environmental geologic investigations of Lake Balaton. - Acta Geologica Hungarica 38, 355-376.

CSERny T., PrónAy Zs. \& NeducZA B. 2005: A Balatonon végzett korábbi szeizmikus mérések újraértékelése. - MÁFI Évi Jelentése a 2004. évról, 273-283.

CSERny T., Prónay Zs., NAgyné Bodor E., Szurominé Korecz A. \& SÁrdy J. 2020: A Balaton földtani kutatása a XX. század végéig. - In: BABINSZKi E. \& HoRváth F. (szerk.): A Balaton kutatása Lóczy Lajos nyomdokán. Magyarhoni Földtani Társulat, Budapest, 189-213. 
DitTRIch, M. \& Oвsт, M. 2004: Are picoplankton responsible for calcite precipitation in lakes? - Ambio 33, 559-564. https://doi.org/ 10.1579/0044-7447-33.8.559

Dobolyi, E. \& BiDLó, G. 1980: Contribution to the study on bottom sediment in Lake Balaton. I. Determination of phosphorus minerals in the sediment. - Internationale Revue der gesamten Hydrobiologie 65, 489-497.

EMszT K. 1911: A Balaton fenékiszapjának és altalajának chemiai alkata. - In: Lóczy L. (szerk.): A Balatonnak és környékének fizikai földrajza. Magyar Királyi Földrajzi Társaság Balaton-bizottsága, Budapest, 1-16.

EnTZ G. \& SEBESTYÉN O. 1942: A Balaton élete. - Királyi Magyar Természettudományi Társaság, 366 p.

Fodor, M. A., Ható, Z. \& PóSFAI, M. 2020: The role of clay surfaces in the heterogeneous nucleation of calcite: Molecular dynamics simulations of cluster formation and attachment. - Chemical Geology 538, 119497. https://doi.org/10.1016/j.chemgeo.2020.119497

Fussmann, D., Von Hoyningen-Huene, A. J. E., Reimer, A., Schneider, D., Babková, H., Peticzka, R., Maier, A., Arp, G., Daniel, R. \& MeisteR, P. 2020: Authigenic formation of Ca-Mg carbonates in the shallow alkaline Lake Neusiedl, Austria. - Biogeosciences 17/7, 2085-2106. https://doi.org/10.5194/bg-17-2085-2020

GaINES, A. M. 1977: Protodolomite redefined. - Journal of Sedimentary Petrology 47, 543-546.

Gavryushinin, P. N., Recnik, A., Daneu, N., Sagatov, N., Belonoshro, A. B., Popov, Z. I., Ribic, V. \& Litasov, K. D. 2019: Temperature induced twinning in aragonite: transmission electron microscopy experiments and ab initio calculations. - Zeitschrift für Kristallographie-Crystalline Materials 234/2, 79-84. https://doi.org/10.1515/zkri-2018-2109

Gebauer, D., Raiteri, P., Gale, J. D. \& Cölfen, H. 2018: On classical and non-classical views on nucleation. - American Journal of Science 318/9, 969-988. https://doi.org/10.2475/09.2018.05

GregG, J. M., Bish, D. L., KaczmareK, S. E. \& Machel, H. G. 2015: Mineralogy, nucleation and growth of dolomite in the laboratory and sedimentary environment: A review. - Sedimentology 62/6, 1749-1769. https://doi.org/10.1111/sed.12202

HAAS J. \& HIPS K. 2020: A rejtelmes dolomit. - Földtani Közlöny 150/2, 233-233. https://doi.org/10.23928/foldt.kozl.2020.150.2.233

HÁMOR, T. 1994: The occurrence and morphology of sedimentary pyrite. - Acta Geologica Hungarica 37, 153-181.

HERODEK, S. \& IstVÁNovics, V. 1986: Mobility of phosphorus fractions in the sediments of Lake Balaton. - Hydrobiologia 135, $149-154$. https://doi.org/10.1007/bf00006466

HLAVAY, J. \& POLYÁK, K. 2002: Investigation on the pollution sources of bottom sediments in the Lake Balaton. - Microchemical Journal 73/1-2, 65-78. https://doi.org/10.1016/s0026-265x(02)00053-x

Hu, Q., Nielsen, M. H., Freeman, C. L., Hamm, L. M., TaO, J., Lee, J. R. I., Han, T. Y.-J., Becker, U., Harding, J. H. \& Dove, P. M. 2012: The thermodynamics of calcite nucleation at organic interfaces: Classical vs. non-classical pathways. - Faraday Discussions 159/1, 509-523. https://doi.org/10.1039/c2fd20124k

IstVÁnOVICS, V. 2008: The role of biota in shaping the phosphorus cycle in lakes. - Freshwater Reviews 1, 143-174. https://doi.org/ $10.1608 /$ frj-1.2.2

Istvánovics, V., Herodek, S. \& Szilágyi, F. 1989: Phosphate adsorption by different sediment fractions in Lake Balaton and its protecting reservoirs. - Water Research 23, 1357-1366. https://doi.org/10.1016/0043-1354(89)90074-2

Istvánovics, V., Honti, M., ToRma, P. \& Kousal, J. 2020: Climate change driven regime shift and record-setting algal bloom in large, shallow Lake Balaton, Hungary. - Harmful Algae közlésre benyújtva.

JI, H. M., YANG, W., CHEN, D. L. \& LI, X. W. 2020: Natural arrangement of fiber-like aragonites and its impact on mechanical behavior of mollusk shells: A review. - Journal of the Mechanical Behavior of Biomedical Materials 110, 103940. https://doi.org/ 10.1016/j.jmbbm.2020.103940

Kern, Z., KÁZmér, M., Müller, T., Specziár, A., Németh, A. \& VÁcZI, T. 2017: Fusiform vateritic inclusions observed in European eel (Anguilla anguilla L.) sagittae. - Acta Biologica Hungarica 68/3, 267-278. https://doi.org/10.1556/018.68.2017.3.4

Kiss A., Visnovitz F., Timár G., HÁmori Z. \& Horváth F. 2018: A Tihanyi-kút morfológiája ultranagy felbontású balatoni szeizmikus mérések alapján. - Magyar Geofizika 59/2,53-64.

Lóczy L. 1913: A Balaton tudományos tanulmányozásának eredményei. - Magyar Királyi Földrajzi Társaság, Budapest, 617 p.

Lóczy L. 1920: A Balaton földrajzi és társadalmi állapotainak leírása. - Hornyánszky Nyomda, Budapest, 194 p.

Ma, G., He, X., JiAnG, X., LiU, H., Chu, J. \& XiaO, Y. 2020: Strength and permeability of bentonite-assisted biocemented coarse sand. Canadian Geotechnical Journal, in press. https://doi.org/10.1139/cgj-2020-0045

Magyari E., Szádovszky L., Kones P., Abraham V., Szabó Z., Csüllög G. \& Bihari, Á. 2019: A dunántúli táj felszínborítás változása a középkortól napjainkig pollen alapú kvantitatív rekonstrukciók alapján. - In: BosNAKOFF M. \& FőZY I. (szerk.): 22. Magyar Őslénytani Vándorgyúlés, Program, elóadáskivonatok, kirándulásvezetó. Magyarhoni Földtani Társulat, Döbrönte, 24-25.

Márton P., Babinszki E., Dövényi P., Drahos D., Galsa A., Horváth F., Lipovics T., Mártonné Szalay E., Puszta S., Salát P., SURÁNYI G., SZÉKELY B., TÓTH T. \& WINDHOFFER G. 2007: Integrált kutató módszer kifejlesztése negyedidőszaki környezeti állapotok geofizikai vizsgálatára. Zárójelentés a T44765 sz. OTKA pályázathoz (2003-2005). - Budapest.

MÁTÉ F. 1987: A Balaton-meder recens üledékeinek térképezése. - A Magyar Állami Földtani Intézet Évi Jelentése az 1985. évról, 367-379.

Molnár, Z., Pekker, P. \& PósfaI, M. 2020a: Clay minerals affect calcium (magnesium) carbonate precipitation and aging. - Earth and Planetary Science Letters, közlésre benyújtva.

Molnár, Z., PekKer, P., JaKAB, M., DóDony, I., VitÁL, Z. \& PóSFAi, M. 2020b: Nanostructure of biogenic aragonite: a study of otoliths and bivalve shells from a freshwater environment. - EGU General Assembly Conference Abstracts, 21996. https://doi.org/ 10.5194/egusphere-egu2020-21996

MÜLLER, G. 1970: High-magnesian calcite and protodolomite in Lake Balaton (Hungary) sediments. - Nature 226, 749-750. https://doi.org/10.1038/226749a0

MüLLER, G. 1981: Heavy metals and nutrients in sediments of Lake Balaton, Hungary. - Environmental Technology 2/1, 39-48. https://doi.org/10.1080/09593338109384020 
MÜLLER, G. \& WAGNER, F. 1978: Holocene carbonate evolution in Lake Balaton (Hungary): a response to climate and impact of man. In: MAtTer, A. \& TuCKer, M. E. (szerk.): Modern and ancient lake sediments. Special Publications of the International Association of Sedimentologists. Blackwell Scientific Publications, 57-81. https://doi.org/10.1002/9781444303698.ch4

NYIRŐ-KóSA I. \& PÓSFAI M. 2007: Mágneses baktériumok a Balatonban. - Hidrológiai Közlöny 87,90-92.

Nyirő-Kósa, I., Rostási, Á., BereczK-TompA, É., CorA, I., Koblar, M., Kovács, A. \& Pósfai, M. 2018: Nucleation and growth of Mgbearing calcite in a shallow, calcareous lake. - Earth and Planetary Science Letters 496, 20-28. https://doi.org/10.1016/ j.eps1.2018.05.029

NyOKABI, W. 2020: Potential dissolution of calcium carbonate shells in a freshwater environment. -MSc Thesis, University of Pannonia, Veszprém, $76 \mathrm{p}$.

Padisák, J., Scheffler, W., Sípos, C., Kasprzak, P., Koschel, R. \& Krienitz, L. 2003: Spatial and temporal pattern of development and decline of the spring diatom populations in Lake Stechlin in 1999. - Archiv für Hydrobiologie Beiheft Advances in Limnology 58, $135-155$.

Pósfai, M. \& Arató, B. 2000: Magnetotactic bacteria and their mineral inclusions from Hungarian freshwater sediments. - Acto Geologica Hungarica 43/4, 463-476.

Pósfai, M. \& Dunin-Borkowski, R. E. 2006: Sulfides in biosystems. - Reviews in Mineralogy and Geochemistry 61/1, 679-714. https://doi.org/10.1515/9781501509490-014

Pósfai M. \& G.-Tóth L. 2020: A Balaton iszapjának ásványai. - In: BABINszKi E. \& Horváth F. (szerk.): A Balaton kutatása Lóczy Lajos nyomdokán. Magyarhoni Földtani Társulat, Budapest, 233-249.

Pósfai M., Molnár Z., Rostási Á., Fodor M. \& Cserny T. 2019a: A Balaton üledékének kutatása. - In: Budai T., Palotás K. \& Piros O. (szerk.): Földtani és Geofizikai Vándorgyúlés. - Magyarhoni Földtani Társulat és Magyar Geofizikusok Egyesülete, Balatonfüred, 16-19.

Pósfai, M., Molnár, Z., Pekker, P., Dódony, I., Frisia, S. \& Meister, P. 2019b: Microstructure of magnesium-bearing carbonates precipitating from shallow fershwater lakes. - GSA Annual Meeting in Phoenix, Arizona, 335892. https://doi.org/10.1130/abs/ 2019am-335892

Rostási Á., Fodor M., Rácz K., Topa B., Weiszburg T. \& Pósfai M. 2019: A Balaton üledékképződésének ásványmérlege. - In: T. Budai, K. PAlotás \& O. PIros (szerk.): Földtani és Geofizikai Vándorgyúlés. Magyarhoni Földtani Társulat és Magyar Geofizikusok Egyesülete, Balatonfüred, 115-117.

Rostási, Á., RÁcz, K., Fodor, M., TopA, B., Molnár, Z., Weiszburg, T. \& Pósfai, M. 2020: Pathways of carbonate sediment accumulation in a large, shallow lake. - manuscript in preparation.

Ruiz-Agudo, E., Putnis, C. V. \& Putnis, A. 2014: Coupled dissolution and precipitation at mineral-fluid interfaces. - Chemical Geology 383, 132-146. https://doi.org/10.1016/j.chemgeo.2014.06.007

Schöll-BARNA, G. 2011: An isotope mass balance model for the correlation of freshwater bivalve shell (Unio pictorum) carbonate ${ }^{18} \mathrm{O}$ to climatic conditions and water ${ }^{18} \mathrm{O}$ in Lake Balaton (Hungary). - Journal of Limnology 70/2, 272-282. https://doi.org/ 10.4081/jlimnol.2011.272

Schöll-Barna, G., Demény, A., Serlegi, G., FÁbián, S., SüMegi, P., Fórizs, I. \& Bajnóczi, B. 2012: Climatic variability in the Late Copper Age: stable isotope fluctuation of prehistoric Unio pictorum (Unionidae) shells from Lake Balaton (Hungary). - Journal of Paleolimnology, 1-14. https://doi.org/10.1007/s10933-011-9561-6

Smolders, E., Baetens, E., Verbeeck, M., Nawara, S., Diels, J., Verdievel, M., Peeters, B., De Cooman, W. \& Baken, S. 2017: Internal loading and redox cycling of sediment iron explain reactive phosphorus concentrations in lowland rivers. - Environmental Science \& Technology 51/5, 2584-2592. https://doi.org/10.1021/acs.est.6b04337

Somlyódy, L. \& VAN Straten, G. 1986: Modeling and managing shallow lake eutrophication - with application to Lake Balaton. Springer, Berlin, 388 p. https://doi.org/10.1007/978-3-642-82707-5

Sosso, G. C., Chen, J., Cox, S. J., Fitzner, M., Pedevilla, P., Zen, A. \& Michaelides, A. 2016: Crystal nucleation in liquids: Open questions and future challenges in molecular dynamics simulations. - Chemical Reviews 116/12, 7078-7116. https://doi.org/ 10.1021/acs.chemrev.5b00744

Sun, W., Jayaraman, S., Chen, W., Persson, K. A. \& Ceder, G. 2015: Nucleation of metastable aragonite CaCO in seawater. Proceedings of the National Academy of Sciences 112/11, 3199-3204. https://doi.org/10.1073/pnas.1423898112

SüMEgi, P., GulYÁs, S. \& JAKAB, G. 2008: Holocene paleoclimatic and paleohydrological changes in Lake Balaton as inferred from a complex quantitative environmental historical study of a lacustrine sequence of the Szigliget embayment. - Documenta Praehistorica 35/1, 33-43. https://doi.org/10.4312/dp.35.3

SzABÓ Z. \& BoDOKY T. 2019: Eötvös Loránd, a geofizikus, a múszeres geofizikai kutatások ,atyja”. - In: DoBsZAY T., EsTóK J., GYÁNI G. \& PATKós A. (szerk.): Eötvös Loránd Emlékalbum. Kossuth Kiadó, Budapest, 45-58.

SZESZTAY K. 1961: A Balaton medrének feltöltődésérôl. - Hidrológiai Tájékoztató, 1961. dec., 48.

SzESZTAY K. 1966: A Balaton feliszapolódásával kapcsolatos kutatások 1963-64. Beszámoló a kutatások koordinálására létesült intézetközi munkaközösség tevékenységérôl. - VITUKI adattára.

Tapolczai, K., Bouchez, A., Stenger-Kovács, C., PADIsÁk, J. \& Rimet, F. 2016: Trait-based ecological classifications for benthic algae: review and perspectives. - Hydrobiologia 776/1, 1-17. https://doi.org/10.1007/s10750-016-2736-4

Thompson, J. B., Schultze-Lam, S., Beveridge, T. J. \& Des Marais, D. J. 1997: Whiting events: biogenic origin due to the photosynthetic activity of cyanobacterial picoplankton. - Limnology and Oceanography 42/1, 133-141. https://doi.org/10.4319/ lo.1997.42.1.0133

TOMPA, É., NyIRŐ-KósA, I., Rostási, Á., CSERnY, T. \& PósfAI, M. 2014: Distribution and composition of Mg-calcite and dolomite in the water and sediments of Lake Balaton. - Central European Geology 57, 113-136. https://doi.org/10.1556/ceugeol.57.2014.2.1 
Tóth, Z., Tóth, T., Szafián, P., Horváth, A., Hámori, Z., Dombrádi, E., Fekete, N., Spiess, V. \& Horváth, F. 2010: Szeizmikus KUTATÁSOK a Balatonon. - Földtani Közlöny 140/4, 355-366.

Treitz P. 1911: A Balaton tó fenékiszapjának és altalajának fizikai alakulása és ásványtani összetétele. - In: Lóczy L. (szerk.): A Balatonnak és környékének fizikai földrajza. Magyar Királyi Földrajzi Társaság Balaton-bizottsága, Budapest, 1-26.

TULLNER T. 2002: A Balaton vízszintváltozásai földtudományi adatbázisának térinformatikai feldolgozása tükrében. - PhD Thesis, Eötvös Loránd University, Budapest, 142 p.

Tullner, T. \& CSERny, T. 2003: New aspects of lake-level changes: Lake Balaton, Hungary. - Acta Geologica Hungarica 46/2, 215-238.

VIRÁG Á. 1998: A Balaton múltja és jelene. - Egri Nyomda Kft., Eger, 904 p.

Visnovitz F., Horváth F., Surányi G., Magyari Á., Sant, K., Csoma V., Sujan, M., Braucher, R., Magyar I. \& Sztanó O. 2017: A Balaton alatti pannóniai rétegeket mintázó TFM-1/13 kutatófúrás komplex vizsgálatának eredményei. - Földtani Közlöny 147/3, 283-296. https://doi.org/10.23928/foldt.kozl.2017.147.3.283

Visnovitz F., Horváth F., HÁmori Z. \& Tóth T. 2019: Szeizmikus kutatások a Balatonon: az elmúlt három évtized balatoni vízi szeizmikus kutatásai az ELTE-GEOMEGA szemszögéből. - In: Budai T., PALOTÁs K. \& Piros O. (szerk.): Földtani és Geofizikai Vándorgyúlés. Magyarhoni Földtani Társulat és Magyar Geofizikusok Egyesülete, Balatonfüred.

Zlinszky A., Molnár G. \& SzéKely B. 2010: A Balaton vízmélységének és tavi üledékvastagságának térképezése vízi szeizmikus szelvények alapján. - Földtani Közlöny 140/4, 429-438.

Zólyomi B. 1952: Magyarország növénytakarójának fejlődéstörténete az utolsó jégkorszaktól. - Az MTA Biológiai Tudományok Osztálya Közleményei 1/4, 491-543.

Kézirat beérkezett: 2020. 09. 01. 